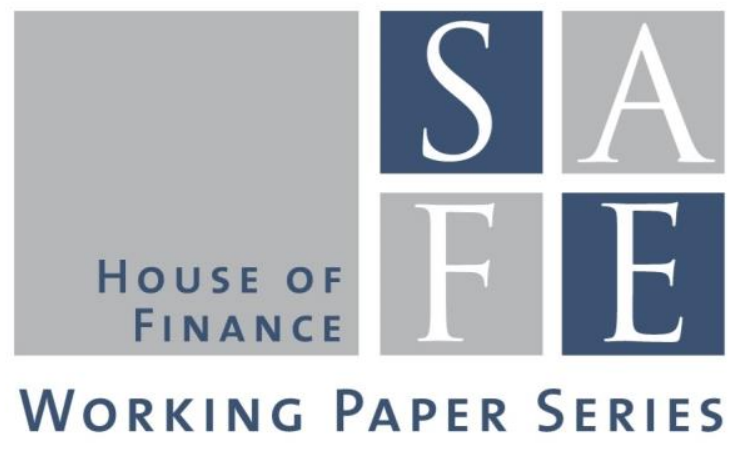

Douglas Cumming - Jochen Christian Werth - Yelin Zhang

\title{
Governance in Entrepreneurial Ecosystems: \\ Venture Capitalists vs. Technology Parks
}

SAFE Working Paper No. 135

SAFE I Sustainable Architecture for Finance in Europe A cooperation of the Center for Financial Studies and Goethe University Frankfurt 


\section{Non-Technical Summary}

With the increasing emergence of several regulatory changes, particularly since the aftermath of the financial crisis in 2007/2008, and due to enhanced regulatory costs therewith associated, public IPOs have become a relatively less common form of exit for investors in start-ups backed by venture capitalists (VCs) in the United States. At the meantime, there has been a growth in acquisition exits for start-ups, including venture capital (VC) backed start-ups. Given this new environment where investors in start-ups more often successfully exit via acquisitions, in this paper, we aim to explore the avenues on which start-ups achieve such an acquisition outcome. We focus our comparison on two different types of important resources for start-ups: VC finance, and technology parks. We show that these two routes have substantially different governance paths: technology parks are characterized by advice and networks, while VCs are characterized by control.

The comparative dearth of IPOs relative to acquisitions post financial crisis in the United States has given rise to a marked shift in the entrepreneurial ecosystem. If a start-up achieves an IPO then the founding entrepreneur typically becomes the CEO of the publicly traded company. By contrast, acquisition exits are peculiar in the sense that the founding entrepreneur of the start-up must either become an employee in the merged entity, or leave to work for another start-up or become an angel investor. Often, entrepreneurs are very reluctant to sell a firm that they had created, and it is an emotional event to give up the entity by merging it with another one and thereby lose control. VCs, by contrast typically only care about the financial return to an investment and do not have non-pecuniary incentives that entrepreneurs may have. For this reason, it is possible that there are conflicts of interest between outside investors and entrepreneurs when investors want to maximize the return on investment through an acquisition and entrepreneurs do not wish to exit via an acquisition.

Prior to the financial crisis when IPOs were more feasible, the tension between the choice of IPOs versus acquisitions was more pronounced in the United States. Post-financial crisis, the tension is not so much whether the founding entrepreneur will give up control in an acquisition exit, but instead when the entrepreneur will give up control. If the entrepreneur obtains VC finance, the entrepreneur gives up board seats and other contractual rights through which VCs can exercise control and even replace the founding entrepreneur as CEO prior to an exit event. If the entrepreneur does not obtain VC finance, there is a smaller chance that the entrepreneur will achieve a successful acquisition exit and greater likelihood of liquidation unless the entrepreneur has access to other forms of support in the entrepreneurial ecosystem.

Apart from VC finance, incubators and technology parks are a widely recognized form of support for entrepreneurs. Technology parks, unlike VCs, do not take equity cash flow rights and various control rights over the companies that they help. Instead, technology parks offer a physical space and a support network (from technology park staff or other tenant companies) to enable a start-up 
to successfully grow. As well, an affiliation with a technology park can enable visibility to potential new investors and/or strategic acquirers. Hence, we expect that firms making use of technology parks are more likely to successfully grow through the support and advice, leading to acquisitions. The critical governance difference with between technology parks and VC finance is that with VC finance the founding entrepreneur is typically replaced as the CEO years prior to the acquisition, unlike that with technology parks, unless a VC is involved in the firm together with the technology park.

In this paper, we introduce a new hand-collected dataset of 251 software/internet start-up firms from Crunchbase, a highly detailed tech entrepreneur webpage resource. A total of 181 of these firms received either angel or VC finance, 99 were affiliated with a technology park, and 78 had angel or VC finance and were affiliated with a technology park. We followed in detail all of these firms from January 2007 to May 2014. The selected timeframe enables us to track financing activities for most of the start-ups since their establishment. More precisely, we can observe whether or not and when firms were acquired, liquidated, or remained private, whether or not and when the founding entrepreneur was replaced as CEO, the timing of board changes and other details on the structure and changes in the board over time.

Our findings underline the important role of technology parks in the entrepreneurial finance ecosystem. First, it can be argued that entrepreneurial firms, which obtain VC finance, are more likely to experience replacement (normally after 1.5 years) of the founding entrepreneur as CEO, and subsequently exit by acquisition (normally after 6.5 years). VCs take control positions through their role on boards and with other contractual rights that can bring about changes in a start-up necessary to effect a successful acquisition. By contrast, entrepreneurs that affiliate themselves with technology parks are more likely to achieve an acquisition exit without experiencing CEO replacement. The probability of and time to acquisition, however, are significantly mitigated with VCs and technology parks come together, which is most likely due to differing objectives and conflicts of interest. Overall, both, VCs and technology parks, have significant governance roles in the entrepreneurial ecosystem. It remains for future research to examine a number of extensions on how and where to optimize their respective roles in entrepreneurial development and innovation. 


\title{
Governance in Entrepreneurial Ecosystems: Venture Capitalists vs. Technology Parks
}

\author{
Douglas Cumming \\ Professor and Ontario Research Chair \\ York University - Schulich School of Business \\ 4700 Keele Street \\ Toronto, Ontario M3J 1P3 \\ Canada \\ http://ssrn.com/author $=75390$ \\ dcumming@schulich.yorku.ca
}

\author{
Jochen Christian Werth \\ Goethe University Frankfurt \\ School of Economics and Business Administration \\ Grüneburgplatz 1 \\ 60323 Frankfurt, Germany \\ Phone: +49-6979834821 \\ werth@em.uni-frankfurt.de
}

Yelin Zhang
York University - Schulich School of Business
4700 Keele Street
Toronto, Ontario M3J 1P3
Canada
http://www.schulich.yorku.ca/
ZhangY12@schulich.yorku.ca

March 25, 2016

\footnotetext{
* We are indebted to Sofia Johan and the seminar participants at York University for helpful comments. We gratefully acknowledge research support from the Research Center SAFE, funded by the State of Hessen initiative for research LOEWE.
} 


\title{
Governance in Entrepreneurial Ecosystems: Venture Capitalists vs. Technology Parks
}

\begin{abstract}
We argue two alternative routes that lead entrepreneurial start-ups to acquisition outcomes instead of liquidation. On one hand, acquisitions can come about through the control route with external financers such as venture capitalists (VCs). VCs take control through their board seats along with other contractual rights that can bring about changes in a start-up necessary to successfully attract a strategic acquirer. Consistent with this view, we show that VCs often replace the founding entrepreneur as CEO long before an acquisition exit. On the other hand, acquisitions can come about through advice and support provided to the start-up, such as that provided by an incubator or technology park. Based on a sample of 251 Crunchbase companies in the U.S. over the years 2007 to 2014, we present evidence that is strongly consistent with these propositions. Further, we show that the data indicate a tension between VC-backing of start-ups resident in technology parks insofar as such start-ups are slower to become, and less likely to be, acquired.
\end{abstract}

Keywords: Entrepreneurship, Entrepreneurial Finance, Governance, Technology Park, Incubator, Board of Directors, Venture Capital, Angel

JEL Codes: G23, G24, L26 


\section{Introduction}

Since the financial crisis, there has been a growth in acquisition exits for start-ups, including VC-backed start-ups. The relatively higher costs associated with going public, attributable in part to regulatory changes around the IPO process (Ferran, Moloney, Hill, and Coffee, 2012), have made IPOs less common (Ritter, 2016) and acquisition exits much more common for entrepreneurial start-ups, particularly in the United States (Cumming and Johan, 2013a). Given this new environment where investors in start-ups more often successfully exit via acquisitions, in this paper we explore the avenues on which start-ups achieve such an acquisition outcome. We focus our comparison on two different types of important resources for start-ups: venture capital (VC) finance, and technology parks. We show that these two routes have substantially different governance paths: technology parks are characterized by advice and networks, while VCs are characterized by control.

The comparative dearth of IPOs relative to acquisitions post financial crisis in the U.S. has given rise to a marked shift in the entrepreneurial ecosystem. If a start-up achieves an IPO then the founding entrepreneur typically becomes the CEO of the publicly traded company. By contrast, acquisition exits are peculiar in the sense that the founding entrepreneur of the start-up must either become an employee in the merged entity, or leave to work for another start-up or become an angel investor (Cumming, Werth and Walz, 2016). Often, entrepreneurs are very reluctant to sell a firm that they had created, and it is an emotional event to give up the entity by merging it with another one and thereby lose control (Petty, Martin, and Kensinger, 1999). Venture capitalists (VCs), by contrast typically only care about the financial return to an investment and do not have non-pecuniary incentives that entrepreneurs may have. For this reason, it is possible that there are conflicts of interest between outside investors and 
entrepreneurs when investors want to maximize the return on investment through an acquisition and entrepreneurs do not wish to exit via an acquisition.

Prior to the financial crisis when IPOs were more feasible, the tension between the choice of IPOs versus acquisitions was more pronounced in the U.S. Post-financial crisis, the tension is not so much whether the founding entrepreneur will give up control in an acquisition exit, but instead when the entrepreneur will give up control. If the entrepreneur obtains VC finance, the entrepreneur gives up board seats and other contractual rights through which VCs can exercise control and even replace the founding entrepreneur as CEO prior to an exit event. If the entrepreneur does not obtain VC finance, there is a smaller chance that the entrepreneur will achieve a successful acquisition exit and greater likelihood of liquidation unless the entrepreneur has access to other forms of support in the entrepreneurial ecosystem.

Apart from VC finance, incubators and technology parks are a widely recognized form of support for entrepreneurs (Hansen, Chesbrough, Nohria, and Sull, 2000). Technology parks, unlike VCs, do not take equity cash flow rights and various control rights over the companies that they help. Instead, technology parks offer a physical space and a support network (from technology park staff or other tenant companies) to enable a start-up to successfully grow. As well, an affiliation with a technology park can enable visibility to potential new investors and/or strategic acquirers (Löfsten and Lindelöf, 2002; Squicciarini, 2009; Cumming and Johan, 2013b). Hence, we expect that firms making use of technology parks are more likely to successful grow through the support and advice, leading to acquisitions. The critical governance difference with between technology parks and VC finance is that with VC finance the founding entrepreneur is typically replaced as the CEO years prior to the acquisition, unlike that with technology parks, unless a VC is involved in the firm together with the technology park. 
In this paper we introduce a new hand-collected dataset of 251 software/Internet start-up firms from Crunchbase, an extremely detailed tech entrepreneur webpage resource. A total of 181 of these firms received either angel or VC finance, 99 were affiliated with a technology park, and 78 had angel or VC finance and were affiliated with a technology park. We know whether or not and when firms were acquired, liquidated, or remained private, whether or not and when the founding entrepreneur was replaced as CEO, the timing of board changes and other details on the structure and changes in the board over time. We followed in detail all of these firms from January 2007 to May 2014. The data indicate that entrepreneurs financed by VCs typically lead to CEO replacement (normally after 1.5 years) and then acquisition exits (normally after 6.5 years). Further, the data indicate that start-ups that make use of technology parks, not VCs, are less likely to experience CEO replacement and yet still achieve an acquisition exit. But when VCs are on the board of a start-up that is resident at a technology park, exit via acquisition is delayed and CEO replacement is much more likely and faster. These details are described herein.

This paper is related to a long literature on VCs (Mason and Harrison, 1995, 2002a,b; Cumming, 2008; Jolink and Niesten, 2016, and angels (Goldfarb et al., 2007, 2012; DeGennaro, 2013; DeGennaro and Dwyer, 2014), and a separate stream of literature on incubators and technology parks (Hansen, Chesbrough, Nohria, Sull, 2000; Lofsten and Lindelof, 2002; Squicciarini, 2009; Cumming and Fischer, 2012; Cumming and Johan, 2013b; Gykpali, Kokkinos, and Bouras, 2016). Few papers study VCs, angels, and technology parks at the same time. Perhaps the paper closest to ours is a study by Chen (2009) on 122 start-ups with VC or incubator support, who finds both VCs and incubators moderate the role of technology commercialization on new venture performance. Cosh, Cumming, and Hughes (2009) note that 
the literature on entrepreneurial finance is highly segmented by virtue of the data coming from the source of capital, and not from the entrepreneurial firm, and hence papers on VC for example typically only know about VC and no other forms of finance. In this paper, we use data from entrepreneurial firms and use a recent sample of firms that do and do not have a wide range of sources of finance, and that are and are not in incubators/technology parks, etc. We document changes over time among these firms to understand the governance implications of different sources of finance, boards, and support mechanisms such as incubators, among other things as documented herein.

This paper is organized as follows. Section 2 develops the hypotheses. Section 3 introduces and describes the data. Section 4 presents the multivariate tests. Limitations and extensions are discussed in section 5. The last section provides a brief summary and concluding remarks.

\section{Hypotheses}

Since the introduction of Sarbanes Oxley legislation in the U.S. in June 2002, and further regulatory changes since the aftermath of the financial crisis which started in the first week of August 2007, IPOs have become a relatively less common form of exit for investors in start-ups backed by VCs in the U.S. (Cumming and Johan, 2013a; Ritter, 2016) due to the very large regulatory costs and changes in rules for taking companies public (Ferran, Moloney, Hill, and Coffee, 2012). The economics of investment banks in the aftermath of the financial crisis is such that firms need larger valuations to be taken public, and have substantially larger sales at the time of IPO and are older (Ritter, 2016). For example, from 1980-2002, firms were on average 8 
years old at the time of IPO, while from 2002-2015, firms were on average 12 years old at the time of IPO (Ritter, 2016). VC investments are normally from 2-7 years from time of investment to exit, as VC limited partnership agreements are normally 10 years with an option wind-up investments for a final 1-3 years (Cumming and Johan, 2013a). Because it is tough to take a start-up with a couple of entrepreneurs at a valuation of a few million dollars at the time of investment to a billion dollar plus valuation in 2-7 years, it is now relatively much more common for U.S. VCs to successfully exit their investments in start-ups as acquisitions.

VC governance is characterized by very strong contractual rights and representation on boards of directors that typically enable the investor to replace the founding entrepreneur as the $\mathrm{CEO}$, the right to force an acquisition through drag along and other rights, or some other type sale such as a buyback through redemption rights, or an IPO through demand registration rights (Cumming, 2008). VCs bargain hard at the time of initial investment to acquire these rights, and they are often used to direct governance and exit outcomes, particularly among the more reputable VC funds (Bengtsson and Sensoy, 2011; Cumming and Johan, 2013a).

Entrepreneurs may have non-pecuniary preferences to wait until they can achieve an IPO if they prefer to be the CEO of a publicly traded company. VCs, by contrast, prefer only to maximize their return on investment. And since the aftermath of the financial crisis, this return is most likely achieved by selling the company in an acquisition exit. VC control through board seat representation and other contractual rights will therefore mean that acquisitions are more likely with VC investors than without VC investors. Further, VC control typically gives the VC the right to replace the founding entrepreneur as the CEO, which is often necessary to bring about changes in the firm to enable it to grow sufficiently to become an attractive acquisition target. 
H1. (VC Control): VCs on boards increase the probability of and reduce the time to acquisitions through VCs' exercise of control, which includes an increase in the probability of and a shortening the time to CEO replacement.

A technology park (is a collection of buildings (or a single building in the case of an incubator) that hosts chosen entrepreneurial firms who share resources or services provided by the technology park. Technology parks facilitate technology licensing, establishing trade shows, providing funds for commercialization, and/or distributing and disseminating information about the R\&D activities of its tenants. Technology parks add value to their tenants in many ways: (1) they offer an environment in which there is support provided; (2) they foster complementarities across different firms in the technology park that can facilitate the growth and financing of an entrepreneurial firm; (3) they attract outside investors, such banks, angel investors, and VCs. Firms exit technology parks after they are sufficiently independent and post-revenue and postfinancing such that there are expansion (in terms of both space and geography) and other business reasons to relocate. Prior work is consistent with the view that technology parks significantly facilitate the growth and success of start-ups (Löfsten and Lindelöf, 2002; Squicciarini, 2009; Cumming and Fischer, 2012; Cumming and Johan, 2013a; Cumming et al., 2015).

H2. (Incubator/Technology Park Advice and Support): Technology parks increase the probability of and reduce the time to acquisition through the park's advice and support, which is unrelated to CEO replacement.

A natural question arises as to whether or not VCs are complements or substitutes? That is, for firms with VC investment and based in a technology park, is the advice and support 
provided by a technology park additive or in conflict with the control exercised by the VC? On one hand, more sources of advice and help can benefit the firm if that support is provided in a consistent way. On the other hand, differing sources of advice may come in conflict when the advice provided is in opposite directions or has conflicting interests. For example, a technology park may prefer a different acquirer than the $\mathrm{VC}$ for strategic reasons (such as a local presence for a local firm that helps the technology park in other ways and other firms in the technology park), or could prefer an IPO to an acquisition to build the profile of the technology park. In view of the potential scope of conflicts of interest is much wider than the narrow possibility that the VCs' capitalists' and technology parks' incentives are directly aligned, we expect that conflicts are more likely than not.

H3. (Moderating Impact of VCs on Start-ups at Technology Parks): VCs on boards of entrepreneurial firms resident in technology parks increase the time to acquisition, and exacerbate the probability of and shorten the time to CEO replacement.

\section{Data}

Our analysis is based on firms listed in the CrunchBase online database (see www.CrunchBase.com). CrunchBase was developed and is maintained by TechCrunch, the most influential technology blog in the United States, and has been used in recent academic studies; e.g., Cumming, Walz, and Werth, 2016). Professionals in the technology community can add information to the database, which then goes through an approval process before being made available online. We were able to detect 251 firms in the CrunchBase data which had sufficient details over time on their board characteristics, their financing, whether or not they were part of a technology park, whether or not they received angel or VC finance and if so whether or not those investors also held board seats, whether or 
not the founding entrepreneur was replaced, among other things. We hand-collected information on the founder of each of these startups from LinkedIn pages, personal websites, as well as from other sources such as Bloomberg Businessweek. The details of the variables used are outlined in Table 1. Our data allows us to describe the characteristics of all founder teams.

\section{INSERT TABLE 1 ABOUT HERE}

The startups we analyze were founded in the following years: 1997 (1 firm), 2005 (1 firm), 2007 (190 firms), 2008 (58 firms), and 2009 (1 firm). Our data covers a period from January 2007 to May 2014. The starting point of the period enables us to track financing activities for most of the startups since their establishment.

Table 2 summarizes the cases in which the start-up either joined a technology park and/or a VC or angel investor, and the data are broadly consistent with Hypotheses 1-3. For 49 of the 251 firms there was neither an angel/VC nor a technology park involved with the start-up, and of these firms, 3 were acquired, 15written off, and 31 were still private as at May 2014, and 2 experienced the replacement of the founding entrepreneur as CEO. For 103 of the 251 firms there was an angel/VC but not a technology park involved with the start-up, and of these firms, 37 were acquired, 9 written off, and 57 were still private as at May 2014, and 33 experienced the replacement of the founding entrepreneur as CEO. For 21 of the 251 firms there was not an angel/VC but there was a technology park involved with the start-up, and of these firms, 14 were acquired, 4 written off, and 3 were still private as at May 2014, and 2 experienced the replacement of the founding entrepreneur as CEO. For 78 of the 251 firms there was both an angel/VC and a technology park involved with the start-up, and of these firms, 23 were acquired, 6 written off, and 49 were still private as at May 2014, and 14 experienced the replacement of the founding entrepreneur as CEO. 


\section{INSERT TABLE 2 ABOUT HERE}

The average time to $\mathrm{CEO}$ replacement when a VC was involved was 1.58 years (18.9 months), and 47 of the 181 firms with a VC experienced CEO replacement. The average time to CEO replacement without a VC was 23 months, and 4 of these 70 firms experienced CEO replacement. The average time to CEO replacement with a technology park involved was 1.48 years (17.8 months), and 16 of these 99 firms experienced CEO replacement. The average time to CEO replacement without a technology park was 19.9 months, and 35 of these 152 firms experienced CEO replacement. The average time to acquisition when a VC was involved was 6.33 years (75.9 months), and 60 of the 181 firms with a $\mathrm{VC}$ were acquired. The average time to acquisition without a VC was 77.3 months, and 17 of these 70 firms were acquired. The average time to acquisition with a technology park involved was 6.28 years (75.4 months), and 37 of these 99 firms were acquired. The average time to acquisition without a technology park was 76.5 months, and 40 of these 152 firms were acquired. The average time to liquidation when a VC was involved was 6.36 years (76.4 months), and 15 of the 181 firms with a VC were liquidated. The average time to liquidation without a VC was 74.25 months, and 19 of these 70 firms were liquidated. The average time to liquidation with a technology park involved was 6.22 years (74.6 months), and 10 of these 99 firms were liquidated. The average time to liquidation without a technology park was 75.0 months, and 24 of these 152 firms were liquidated.

Table 3 presents comparison of proportions tests for acquisitions, liquidations and staying private for the firms with and without an outside board member, for having a seed/angel round of external finance, for hiring new employees before or without appointing a new external CEO, for appointing a new CEO after angel or VC investment, for joining a technology park, and for different market conditions (MSCI index in the last exit month above or below the median over 
the sample years). The data in Table 3 further indicate write-offs are significantly more likely without an outside board member ( $6.7 \%$ with an outside board member and $17.4 \%$ without), and this difference is significant at the $5 \%$ level of significance. Write-offs are also more likely if the firm has not hired new employees before or without replacing the founding entrepreneur as CEO (7.9\% with new employees and $17.3 \%$ without new employees) and this difference is significant at the $10 \%$ level.

\section{INSERT TABLE 3 ABOUT HERE}

The data indicate acquisitions are significantly more likely if the firm has a seed/angel round of finance (36.4\% with and $22.0 \%$ without), and this difference is significant at the $5 \%$ level of significance, consistent with Hypothesis 1. Write-offs are significantly less likely when the firm has passed the seed/angel round (6.6\% with and $24.0 \%$ without) and this difference is significant at the $1 \%$ level.

Acquisitions are significantly more likely if the firm had replaced CEO (34.8\% with and $19.4 \%$ without) and this difference is significant at the 5\% level, consistent with Hypothesis 1. Write-offs are more likely if the firm has not replaced the CEO after angel/VC investment (8.7\% with and $26.9 \%$ without) and this difference is significant at the $1 \%$ level.

Acquisitions are significantly more likely if the firm has joined a technology park $(37.4 \%$ with and $26.3 \%$ without) and this difference is significant at the $10 \%$ level, consistent with Hypothesis 2. Joining a technology park shows no significant difference for write-offs and staying private in the comparison tests in Table 3.

Surprisingly, acquisitions are less likely when market conditions are above the median (22.7\% when above and $60.2 \%$ when below) and this difference is significant at the $1 \%$ level. 
Write-offs are also more likely in down market conditions $(21.2 \%$ when less than the median MSCI and 9.7\% when greater than the median MSC) and this difference is significant at the 5\% level. Staying private is more likely when MSCI returns are above the median $(67.6 \%$ when above versus $18.6 \%$ when below), and this difference is significant at the $1 \%$ level.

\section{Regression Analyses}

\subsection{Exit outcomes}

Table 4 presents competing risks exits outcome regressions for acquisitions (Models 1-3) and write-offs (Models 4-6). Different sets of right-hand variables are included to show robustness to different specifications. The hazard rates are shown in Panel A and the coefficient

estimates are shown in Panel B. The Appendix presents analogous logit regressions to show the probability of different exit outcomes with matching sets of right-hand-side variables in the model specifications as those in Table 4.

\section{INSERT TABLE 4 AND FIGURES 1 AND 2 ABOUT HERE}

Table 4 shows that having a VC on the board has a competing risk hazard ratio of 1.98 in Model 1 (2.31 in Model 2 and 2.06 in Model 3), which reflects the faster time to acquisition and greater probability of acquisition, consistent with Hypothesis 1. The significance of VC influence is shown graphically in Figure 1. Similarly, Table A.I in the Appendix shows that the probability of an acquisition is $12.1 \%$ higher (Model 1, and 12.3\% in Model 2 and $11.8 \%$ in Model 3) if there is a $\mathrm{VC}$ on the board. By contrast, having an angel investor on the board does not materially affect the hazard ratio or the probability of an acquisition. 
The likelihood of an acquisition is heightened when the start-up replaces the founding entrepreneur as CEO, and this effect is significant at the 10\% level in each of Models 1-3 in Table 4 with hazard ratios at 1.15 (Models 1 and 2) and 1.28 (Model 3). This effect is graphically shown in Figure 2. Similarly, Table A.I in the Appendix shows that the probability of an acquisition is $10.8 \%$ (Model 1) to $13.9 \%$ (Model 3) higher when the founding entrepreneur is replaced as the CEO. Furthermore, the hazard ratio for liquidations (Table 4 Models 4-6) and probability of liquidation (Table A-1 Models 4-6) is significantly lower when the founding entrepreneur is replaced as the CEO.

Table 4 further shows that the competing risk hazard ratio for joining a technology park is 1.73 in Model 1 (4.14 in Model 2 and 4.40 in Model 3), which reflects the faster time to acquisition and greater probability of acquisition, consistent with Hypothesis 2. However, there is no material change in the time to or likelihood of liquidation when the firm is affiliated with a technology park in Models 4-6 in Table 4. These effects are graphically illustrated in Figure 3. Similarly, Table A.I in the Appendix shows that the probability of an acquisition is $21.0 \%$ higher (Model 2, and 22.5\% higher Model 3) if the start-up joins a technology park.

Table 4 Models 2 and 3 show the interaction between VCs and technology parks has a dampening effect on the competing risks hazard ratio. It is 0.58 in Model 2 and 0.59 in Model 3, implying a longer time and lower probability of an acquisition with VCs are mixed with technology parks, consistent with Hypothesis 3. Similarly, Appendix Table A.I shows a reduction in the probability of an acquisition by $4.5 \%$ in Model 2 and $5.1 \%$ in Model 3 when VCs and technology parks are mixed together. 
Some of the control variables are significant in Table 4 in ways that we would expect as well. For example, bringing in new employees and obtaining angel finance increases the hazard ratio for acquisitions (Models 1-3) and lowers the hazard ratio for write-offs (Models 4-6). Stronger market conditions at the time of exit lower the hazard ratios for acquisitions (not expected) and write-offs (expected). Stronger market conditions are associated with a greater likelihood of the start-up remaining private, possibly with the entrepreneur waiting for better terms in an acquisition or aiming towards an IPO.

\subsection{CEO Replacement}

Table 5 complements the analysis of acquisition and write-off exits in Table 4 by studying when and why firms replace the founding entrepreneur as the CEO. CEO replacement is significantly faster and more likely among firms with a board of directors, particularly with VCs on the board, and when there are other executive managers and fewer other key employees; the significance of these effects is shown graphically in Figures 4. The hazard ratio ranges from 1.78 (Model 4) to 3.83 (Model 8) for having a VC on the board, and the probability of CEO replacement increases by approximately $2 \%$ on average with a VC on the board (see Table A.II in the Appendix). This evidence supports our earlier findings and is consistent with Hypothesis 1 regarding the role of control for $\mathrm{VC}$. Not that by contrast, joining a technology park has no significant effect on CEO replacement/

INSERT TABLE 5 AND FIGURES 3 AND 4 ABOUT HERE 


\section{Limitations and Extensions}

In this paper we focused our comparisons on VCs, angels and technology parks in respect of acquisitions and liquidations. Our detailed data enabled these tests as the data were derived from the entrepreneurial firm, and not from a particular dataset on the source of capital such as a VC dataset as is often the case in VC studies. There are of course limitations to our dataset and ways that this type of analysis can be extended in future studies.

The cutoff point of May 2014 for our sample can lead to potential censorship bias; that is, some firms can be acquired or written off right after May 2014, and other firms may stay private for 20 more years, yet we cannot control for startup activities beyond sample horizon (although our econometric tests carried out above with competing risks hazard models account for such censorship). In addition, we do not have information on startups' operating activities, although angel and VC involvement can signal operating condition in general. As well, we did not present a preliminary analysis of why some firms end up in incubators/technology parks and others obtain VC/angel finance. Our outcomes of interest come many years after the initial assignment, and hence we do not believe selection versus treatment is a major concern with our sample. We do not have ideal instruments to deal with these selection issues, but our investigations with various specifications such as market conditions at the time of entry into VC or incubators suggested our analysis is not distorted by selection effects. Likewise, the selection of particular VC terms and control rights is beyond the scope of our dataset and relevant to the issue of selection versus treatment (see also Cumming, 2008).

To extend our study, with other types of data it would be possible to compare innovation rates associated with VCs and technology parks, in the spirit of work such as Battisti, Colombo 
and Rabbiosi (2015). It would be useful to know precisely what the VCs and the technology parks or incubators do for their investee firms, and when these value added activities come into conflict with each other and why. As well, it would be possible to compare the role of higher education with VCs versus technology parks as done in work such as Bonaccorsi, Colombo Guerini, Lamastra (2015) and Meoli and Vismara (2016). Furhter work could also examine other sources of finance such as crowdfunding (Colombo, Franzoni, Rossi Lamasstra, 2015; Vismara, 2016) and debt finance (Cosh, Cummin and Hughes, 2009). Finally, this type of comparative analysis of entrepreneurial finance could be applied in different institutional settings and different counties (in the spirit of work such as Acs, Audretsch, Lehmann, and Licht, 2016, Audretsch, 2007a, 2007b, Audretsch and Keilbach, 2007; Coad et al., 2016; Engel and Keilbach, 2006; Schillo, Persaud, and Jin (2016),) to better understand the role of institutional constraints and public policy (McCann and Ortega-Argiles, 2016).

\section{Conclusions}

In this paper we argued that VCs and technology parks play very different but important roles in the entrepreneurial finance ecosystem. We examined the post-financial crisis environment over the years 2007-2014 in the U.S. for 251 software/Internet start-up firms that can be tracked on Crunchbase. We argued that entrepreneurial firms that obtain VC finance are more likely to experience replacement of the founding entrepreneur as $\mathrm{CEO}$, and subsequently exit by acquisition. VCs take control positions through their role on boards and with other contractual rights that can bring about changes in a start-up necessary to effect a successful acquisition. By contrast, entrepreneurs that affiliate themselves with technology parks are more 
likely to achieve an acquisition exit without experiencing CEO replacement. The probability of and time to acquisition, however, are significantly mitigated with VCs and technology parks come together, which is most likely due to differing objectives and conflicts of interest. Overall, both VCs and technology parks have significant governance roles in the entrepreneurial ecosystem, and further research could examine a number of extensions on how and where to optimize their respective roles in entrepreneurial development and innovation. 


\section{References}

Acs, Z.J., D.B. Audretsch, E.E. Lehmann, G. Licht, 2016. National systems of entrepreneurship, Small Business Economics, forthcoming

Audretsch, D., 2007a. Entrepreneurship Capital and Economic Growth. Oxford Review of Economic Policy, 23, 63-78.

Audretsch, D., 2007b. The Entrepreneurial Society, Oxford: Oxford University Press.

Audretsch, D., and M. Keilbach, 2007. The Localisation of Entrepreneurship Capital: Evidence from Germany. Regional Science, 86, 351-365.

Battisti, G., Colombo, M.G., Rabbiosi, L., 2015. Simultaneous versus sequential complementarity in the adoption of technological and organizational innovations: the case of innovations in the design sphere, Industrial \& Corporate Change, forthcoming.

Bengtsson, O., B.A. Sensoy, 2011. Investor abilities and financial contracting: Evidence from venture capital, Journal of Financial Intermediation 20, 477-502.

Bonaccorsi, A., Colombo, M.G., Guerini, M., Rossi Lamastra, C., 2015. The effect of Higher Education Institutions on the creation of new firms: Offering comprehensive evidence on the Italian case, Small Business Economics, forthcoming

Chen, C.-J., 2009. Technology commercialization, incubator and venture capital, and new venture performance, Journal of Business Research 62(1), 93-103.

Coad A., Frankish S.J., Roberts G.R. and Storey J.D. ,2016. Predicting new venture survival and growth: Does the fog lift? Small Business Economics, forthcoming

Colombo, M.G., Franzoni, C., Rossi Lamastra, C., 2015. Internal social capital and the attraction of early contributions in crowdfunding, Entrepreneurship Theory \& Practice, forthcoming.

Cosh, A., D.J. Cumming, and A. Hughes, 2009. Outside entrepreneurial capital, Economic Journal 119, 1494-1533.

Cumming, D.J., 2008. Contracts and exits in venture capital finance, Review of Financial Studies 21, 1947-1982.

Cumming, D.J., and S.A. Johan, 2013a. Venture Capital and Private Equity Contracting: An International Perspective, Elsevier Science Academic Press

Cumming, D.J., and S. Johan, 2013b. Technology Parks and Entrepreneurial Outcomes around the World, International Journal of Managerial Finance 9, 279-293. 
Cumming, D.J., and E. Fischer, 2012. Publicly funded business advisory services and entrepreneurial outcomes, Research Policy 41, 467-481.

Cumming, D., U. Walz, and J. Werth, 2016. Entrepreneurial spawning: experience, education, and exit, The Financial Review, forthcoming

DeGennaro, R. and Dwyer, G., 2014. Expected Returns to Stock Investments by Angel Investors in Groups. European Financial Management. 20, 739-755.

DeGennaro, R., 2013. Angel Investors and their Investments. The Oxford Handbook of Entrepreneurial Finance.

Engel, D., and M. Keilbach, 2006. Firm-Level Implications of Early Stage Venture Capital Investment - An Empirical Investigation. Journal of Empirical Finance 14, 150-167.

Ferran, E., N. Moloney, J.G. Hill, J.C. Coffee, Jr., 2012. The Regulatory Aftermath of the Global Financial Crisis Cambridge University Press.

Goldfarb, B., Hoberg, G., Kirsch, D. and Triantis, A., 2012. Does angel participation matter? An analysis of early venture financing. Unpublished working paper.

Goldfarb, B., Hoberg, G., Kirsch, D. and Triantis, A., 2007. Are Angels Preferred Series A Investors? Unpublished Working Paper, University of Maryland.

Gkypali, A., V. Kokkinos, C. Bouras 2016. Science parks and regional innovation performance in fiscal austerity era: Less is more? Small Business Economics, forthcoming.

Hansen, M.T., Chesbrough, H.W., Nohria, N., \& Sull, D.N., 2000. Networked incubators: hothouses of the new economy, Harvard Business Review (September-October), 74-84.

Löfsten, H., and Lindelöf. P. 2002. Science parks and the growth of new technology-based firms - academic-industry links, innovation and markets. Research Policy 31, 859-876.

Mason, C. and Harrison, R., 1995. Closing the regional equity capita gap: The role of informal venture capital. Small Business Economics. 7, 153-172

Mason, C. and Harrison, R., 2002a. Is it worth it? The rates of return from informal venture capital investments. Journal of Business Venturing. 17, 211-236.

Mason, C. and Harrison, R., 2002b. Barriers to investment in the informal VC sector. Entrepreneurship and Regional Development 14, 271-287.

Jolink, A., E. Niesten, 2016. The impact of venture capital on governance decisions in collaborations with start-ups, Small Business Economics (2016) 
Meoli, M., S. Vismara, 2016. University support and the creation of technology and nontechnology academic spin-offs, in Small Business Economics

McCann, P., R. Ortega-Argilés, 2016. Smart specialisation, entrepreneurship and SMEs: issues and challenges for a results-oriented EU regional policy, Small Business Economics, forthcoming

Petty, J.W., J.D. Martin, and J.W. Kensinger, 1999, Harvesting investments in private companies, Morristown, N.J.: Financial Services Research Foundation, Inc.

Ritter, J., 2016. Initial Public Offerings: VC-backed IPO Statistics Through 2015. https://site.warrington.ufl.edu/ritter/files/2016/02/IPOs2015VC-backed.pdf

Schillo, R.S., A. Persaud, M. Jin, 2016. Entrepreneurial readiness in the context of national systems of entrepreneurship, Small Business Economics

Squicciarini, M. 2009. Science parks: seedbeds of innovation? A duration analysis of firms' patenting activity. Small Business Economics Vol. 32, pp. 169-190.

Vismara, S., 2016. Equity retention and social network theory in equity crowdfunding, Small Business Economics, forthcoming 
Table 1. Summary Statistics of Key Variables

This table shows the summary statistics of the key variables we used in Competing Risk analysis. The dataset covers a period from January 2007 to May 2014.

\begin{tabular}{|c|c|c|c|c|c|c|c|c|}
\hline Variable Name by Categories & Definition & Mean & Minimum & $\begin{array}{c}25 \text { th } \\
\text { percentile }\end{array}$ & Median & $\begin{array}{c}75 \\
\text { percentile }\end{array}$ & Maximum & $\begin{array}{l}\text { Standard } \\
\text { Deviation }\end{array}$ \\
\hline \multicolumn{9}{|l|}{$\underline{\text { Start-Up Outcome }}$} \\
\hline Startup is acquired & $\begin{array}{l}\text { Dummy Variable: whether a } \\
\text { startup is acquired in the sample } \\
\text { horizon? Yes }=1, N_{0}=0\end{array}$ & 0.31 & 0 & 0 & 0 & 1 & 1 & 0.46 \\
\hline Startup is written-off & $\begin{array}{l}\text { Dummy Variable: whether a } \\
\text { startup is written-off in the } \\
\text { sample horizon? Yes }=1, N_{0}=1\end{array}$ & 0.14 & 0 & 0 & 0 & 0 & 1 & 0.34 \\
\hline \multicolumn{9}{|l|}{$\underline{\text { Start-Up Characteristics }}$} \\
\hline Startup size & $\begin{array}{l}\text { The size of a startup (in US } \\
\text { dollar) before its first round of } \\
\text { external financing }\end{array}$ & 20789892.43 & 0 & 712000 & 3000000 & 13000000 & $1.10 \mathrm{E}+09$ & 90672060.96 \\
\hline New employees were hired before bringing in new CEO & $\begin{array}{l}\text { Dummy Variable: whether new } \\
\text { employees are hired before the } \\
\text { hire of new CEO? Yes=1, No=0 }\end{array}$ & 0.40 & 0 & 0 & 0 & 1 & 1 & 0.49 \\
\hline Number of all current key employees & $\begin{array}{l}\text { Total number of current key } \\
\text { employees(i.e. developers, IT } \\
\text { experts, technicians) }\end{array}$ & 3.03 & 0 & 0 & 2 & 5 & 19 & 3.69 \\
\hline Number of executive managers & $\begin{array}{l}\text { Total number of executive } \\
\text { managers in a Startup }\end{array}$ & 3.95 & 0 & 1 & 3 & 6 & 31 & 4.33 \\
\hline Startup had joined incubator/technology park & $\begin{array}{l}\text { Dummy Variable: whether a } \\
\text { startup has joined an incubator } \\
\text { or technology park in the past? } \\
\text { Yes }=1, \mathrm{No}=0\end{array}$ & 0.31 & 0 & 0 & 0 & 1 & 1 & 0.46 \\
\hline Startup passed seed/angel stage & $\begin{array}{l}\text { Dummy Variable: whether a } \\
\text { startup has passed seed/angel } \\
\text { stage? Yes }=1, \mathrm{No}=0\end{array}$ & 0.60 & 0 & 0 & 1 & 1 & 1 & 0.49 \\
\hline Startup had a board of directors & $\begin{array}{c}\text { Dummy Variable: whether a } \\
\text { startup has a board of directors? } \\
\text { Yes }=1, \text { No }=0\end{array}$ & 0.57 & 0 & 0 & 1 & 1 & 1 & 0.50 \\
\hline Startup had replaced CEO & $\begin{array}{l}\text { Dummy Variable: whether } \\
\text { startup had replaced CEO in the } \\
\text { sample period? Yes }=1, \text { No }=0\end{array}$ & 0.20 & 0 & 0 & 0 & 0 & 1 & 0.40 \\
\hline
\end{tabular}


Table 1. (Continued)

\begin{tabular}{|c|c|c|c|c|c|c|c|c|}
\hline Variable Name by Categories & Definition & Mean & Minimum & $\begin{array}{c}\text { 25th } \\
\text { percentile }\end{array}$ & Median & $\begin{array}{c}75 \\
\text { percentile } \\
\end{array}$ & Maximum & $\begin{array}{r}\text { Standard } \\
\text { Deviation } \\
\end{array}$ \\
\hline \multicolumn{9}{|l|}{ Board Characteristics } \\
\hline Number of outside board members & $\begin{array}{c}\text { Total number of outside board } \\
\text { members }\end{array}$ & 1.14 & 0 & 0 & 0 & 2 & 9 & 1.76 \\
\hline Number of founding team members on board & $\begin{array}{l}\text { Total number of founding team } \\
\text { members on board }\end{array}$ & 2.3 & 0 & 1 & 2 & 3 & 5 & 1.08 \\
\hline Average board serving time & $\begin{array}{l}\text { Average board serving time in } \\
\text { months }\end{array}$ & 51.51 & 9 & 51.75 & 51.75 & 51.75 & 86 & 12.97 \\
\hline Startup had Angel on board & $\begin{array}{c}\text { Dummy Variable: whether a } \\
\text { startup had Angel on board? } \\
\text { Yes }=1, \mathrm{No}=0\end{array}$ & 0.37 & 0 & 0 & 0 & 1 & 1 & 0.49 \\
\hline Startup had VC on board & $\begin{array}{c}\text { Dummy Variable: whether a } \\
\text { startup had VC on board? } \\
\text { Yes }=1, \text { No }=0\end{array}$ & 0.65 & 0 & 0 & 1 & 1 & 1 & 0.48 \\
\hline Startup had inside chairman & $\begin{array}{c}\text { Dummy Variable: whether a } \\
\text { startup had inside chairman? } \\
\text { Yes }=1, \text { No }=0\end{array}$ & 0.17 & 0 & 0 & 0 & 0 & 1 & 0.37 \\
\hline Startup had founder chairman & $\begin{array}{l}\text { Dummy Variable: whether a } \\
\text { startup had founder chairman? } \\
\text { Yes }=1, \mathrm{No}=0\end{array}$ & 0.18 & 0 & 0 & 0 & 0 & 1 & 0.38 \\
\hline Number of Financial Vehicle Corporations (FVC) on board & $\begin{array}{c}\text { Total number of FVC on startup } \\
\text { board }\end{array}$ & 0.75 & 0 & 0 & 0 & 1 & 8 & 1.32 \\
\hline Number of Corporate Venture Capital (CVC) on board & $\begin{array}{c}\text { Total number of CVC on startup } \\
\text { board }\end{array}$ & 0.02 & 0 & 0 & 0 & 0 & 1 & 0.14 \\
\hline \multicolumn{9}{|l|}{$\underline{\text { Financing Characteristics }}$} \\
\hline Total number of financing rounds & $\begin{array}{l}\text { Total number of financing rounds } \\
\text { a startup had over the sample } \\
\text { period }\end{array}$ & 2.18 & 0 & 1 & 2 & 3 & 8 & 1.42 \\
\hline Average growth rate of external financing amount & $\begin{array}{l}\text { Average growth rate of the } \\
\text { amount of money raised by } \\
\text { startup in all rounds of external } \\
\text { financing }\end{array}$ & 2.61 & -0.67 & 0 & 0 & 1.04 & 232.4 & 15.55 \\
\hline Time span between the first round financing and exist month & $\begin{array}{l}\text { Time span (in month) between the } \\
\text { first round financing and startup } \\
\text { exit month }\end{array}$ & 40 & 6 & 27 & 39.5 & 53 & 81 & 17.95 \\
\hline \multicolumn{9}{|l|}{$\underline{\text { Market Conditions }}$} \\
\hline Local MSCI Index Return on Exit Month & $\begin{array}{l}\text { Local MSCI Index Return when } \\
\text { Startup exited }\end{array}$ & 0.018 & -0.1725 & 0.019 & 0.0251 & 0.0251 & 0.0943 & 0.0278 \\
\hline Local MSCI Index Return on CEO Replacement Month & $\begin{array}{l}\text { Local MSCI Index Return when } \\
\text { Startup replaced CEO }\end{array}$ & 0.0175 & -0.1725 & 0.0251 & 0.0234 & 0.0242 & 0.0917 & 0.0258 \\
\hline
\end{tabular}




\section{Table 2. Summary of Startup Outcome}

This table summarizes the operational outcome of 251 startups in our dataset. The startups we analyze have 3 different outcomes: acquired by another firm, written-off or stayed private. We categorize the outcomes into 4 groups based on 2 conditions: whether a VC firm or Angel Investor invested in the startup, and whether a startup joined an incubator or technology park. The categories Angel/VC and Incubator/Technology Park are not mutually exclusive and hence do not sum to 251. Our dataset covers the period from January 2007 to May 2014

\section{Startup Activities $\quad$ Frequency of Startup Outcome}

CEO

\begin{tabular}{ccc|cccc} 
Count & $\begin{array}{c}\text { Angel/VC } \\
\text { joined? }\end{array}$ & $\begin{array}{c}\text { Joined Incubator/ } \\
\text { Technology Park? }\end{array}$ & Acquired & Written-off & Stay Private & Replacement \\
\hline 49 & No & No & 3 & 15 & 31 & 2 \\
103 & Yes & No & 37 & 9 & 57 & 33 \\
21 & No & Yes & 14 & 4 & 3 & 2 \\
78 & Yes & Yes & 23 & 6 & 49 & 14
\end{tabular}

Count

251

181

99

77

34

140 


\section{Table 3. Probability Allocation on Startup Outcome}

This table presents the probability allocation of startup outcome by 5 types of firm-specific conditions and 1 type of market condition: whether a startup has outside board member, whether a startup has passed seed/angel stage, whether a startup hires new employees before/without appointing new CEO, whether a startup appoints new CEO after Angel/VC investment, whether a startup has joined an incubator/technology park and whether the local MSCI index return on the exit/last month is above median. For each type of condition, the sum of the probabilities of 3 possible outcomes equals 1 . Comparison tests are applied on each firm-specific condition to evaluate its influence on the firm's operational outcome. Standard errors are in brackets. *, **, *** Significant at the $10 \%, 5 \%$, and $1 \%$ levels, respectively.

Startup has Outside Board Member

Startup Passed Seed/Angel Stage

\begin{tabular}{|c|c|c|c|c|c|c|}
\hline & Yes & No & $\mathrm{Z}$ value & Yes & No & $Z$ value \\
\hline Acquired & $\begin{array}{c}0.3667 \\
(0.0508)\end{array}$ & $\begin{array}{c}0.2733 \\
(0.0351)\end{array}$ & -1.54 & $\begin{array}{c}0.3642 \\
(0.0392)\end{array}$ & $\begin{array}{c}0.2200 \\
(0.0414)\end{array}$ & $-2.43 * *$ \\
\hline Written-off & $\begin{array}{c}0.0667 \\
(0.0263)\end{array}$ & $\begin{array}{c}0.1739 \\
(0.0299)\end{array}$ & $2.38 * *$ & $\begin{array}{c}0.0662 \\
(0.0202)\end{array}$ & $\begin{array}{l}0.2400 \\
(0.0427)\end{array}$ & $3.94 * * *$ \\
\hline Stay Private & $\begin{array}{c}0.5667 \\
(0.0522)\end{array}$ & $\begin{array}{c}0.5528 \\
(0.0392)\end{array}$ & -0.21 & $\begin{array}{c}0.5695 \\
(0.0403)\end{array}$ & $\begin{array}{c}0.5400 \\
(0.0498)\end{array}$ & -0.46 \\
\hline
\end{tabular}

Startup Hired New Employees

before/without Appointing New CEO

\section{Startup had Replaced CEO}

\begin{tabular}{|c|c|c|c|c|c|c|}
\hline & Yes & No & $Z$ value & Yes & No & $Z$ value \\
\hline Acquired & $\begin{array}{c}0.3168 \\
(0.0463)\end{array}$ & $\begin{array}{c}0.3000 \\
(0.0374)\end{array}$ & -0.26 & $\begin{array}{c}0.3478 \\
(0.0351)\end{array}$ & $\begin{array}{c}0.1940 \\
(0.0483)\end{array}$ & $-2.35 * *$ \\
\hline Written-off & $\begin{array}{c}0.0792 \\
(0.0269)\end{array}$ & $\begin{array}{c}0.1733 \\
(0.0309)\end{array}$ & $1.94 *$ & $\begin{array}{c}0.0870 \\
(0.0208)\end{array}$ & $\begin{array}{c}0.2687 \\
(0.0542)\end{array}$ & $2.74 * * *$ \\
\hline Stay Private & $\begin{array}{c}0.6040 \\
(0.0487)\end{array}$ & $\begin{array}{c}0.5267 \\
(0.0408)\end{array}$ & -1.13 & $\begin{array}{c}0.5652 \\
(0.0365)\end{array}$ & $\begin{array}{c}0.5373 \\
(0.0609)\end{array}$ & -0.36 \\
\hline Number of observations & 75 & 176 & & 51 & 200 & \\
\hline & \multicolumn{2}{|c|}{$\begin{array}{l}\text { Startup has joined incubator/technology } \\
\text { park }\end{array}$} & \multicolumn{4}{|c|}{$\begin{array}{l}\text { Local MSCI index in exit/last year is } \\
\text { above median }\end{array}$} \\
\hline & Yes & No & $Z$ value & Yes & No & $\mathrm{Z}$ value \\
\hline Acquired & $\begin{array}{c}0.3737 \\
(0.0968)\end{array}$ & $\begin{array}{c}0.2632 \\
(0.0304)\end{array}$ & $-1.86^{*}$ & $\begin{array}{c}0.2271 \\
(0.0291)\end{array}$ & $\begin{array}{c}0.6018 \\
(0.0702)\end{array}$ & $6.02 * * *$ \\
\hline Written-off & $\begin{array}{c}0.1010 \\
(0.0523)\end{array}$ & $\begin{array}{c}0.1579 \\
(0.0233)\end{array}$ & 1.29 & $\begin{array}{c}0.0966 \\
(0.0205)\end{array}$ & $\begin{array}{c}0.2123 \\
(0.0657)\end{array}$ & $2.53 * *$ \\
\hline Stay Private & $\begin{array}{c}0.5253 \\
(0.0981)\end{array}$ & $\begin{array}{c}0.5789 \\
(0.0331)\end{array}$ & 0.84 & $\begin{array}{c}0.6763 \\
(0.0325)\end{array}$ & $\begin{array}{c}0.1859 \\
(0.0428)\end{array}$ & $-7.85^{* * * *}$ \\
\hline Number of observations & 99 & 152 & & 125 & 126 & \\
\hline
\end{tabular}


Table 4. Competing Risks Analysis on Startup Outcome

This table shows the influence of different firm activities on startups' operational outcome using competing risks regressions. Panel A. presents the estimated subhazard ratio (SHR) of different firm activities for startup acquisition and written-off. Subhazard ratio greater than 1stands for positive influence of the activity on the operational outcome of interest; smaller than 1, negative influence. Panel B. presents the coefficients of the same set of competing risks regressions. T values are shown in brackets. *, **, *** Significant at the $10 \%, 5 \%$, and $1 \%$ levels, respectively.

Panel A. Competing Risks Model--Subhazard Ratio Estimation

Event of interest: Startup was acquired (Model 1-3)

\begin{tabular}{|c|c|c|c|c|c|c|c|c|c|}
\hline & \multicolumn{3}{|c|}{ Model 1} & \multicolumn{3}{|c|}{ Model 2} & \multicolumn{3}{|c|}{ Model 3} \\
\hline & SHR & $\begin{array}{l}\text { Robust } \\
\text { Standard } \\
\text { Error }\end{array}$ & $\mathrm{Z}$ & SHR & $\begin{array}{l}\text { Robust } \\
\text { Standard } \\
\text { Error }\end{array}$ & $\mathrm{Z}$ & SHR & $\begin{array}{l}\text { Robust } \\
\text { Standard } \\
\text { Error }\end{array}$ & $\mathrm{Z}$ \\
\hline \multicolumn{10}{|l|}{$\underline{\text { Start-Up Characteristics }}$} \\
\hline Startup size & 1.000 & 0.0000 & 0.29 & 1.000 & 0.0000 & 0.78 & 1.000 & 0.0000 & 1.32 \\
\hline New employees were hired before bringing in new CEO & $1.175^{*}$ & 0.2065 & 1.87 & $1.183^{* *}$ & 0.1925 & 2.25 & $1.203 * *$ & 0.1705 & 2.45 \\
\hline Startup had joined incubator/technology park & $1.731 *$ & 1.6403 & 1.89 & $4.141 * *$ & 2.3998 & 2.45 & $4.402 * *$ & 2.5652 & 2.54 \\
\hline Startup passed seed/angel stage & $1.091^{*}$ & 0.3585 & 1.66 & $1.358^{*}$ & 0.4705 & 1.93 & $1.409 * *$ & 0.4777 & 2.01 \\
\hline \multicolumn{10}{|l|}{ Board Characteristics } \\
\hline Number of outside board members & & & & $1.160 *$ & 0.0885 & 1.95 & $1.174 * *$ & 0.0914 & 2.06 \\
\hline Number of founding team members on board & & & & $1.239 *$ & 0.1537 & 1.73 & $1.241 *$ & 0.1492 & 1.81 \\
\hline Average board serving time & & & & & & & $0.978 * * *$ & 0.0081 & -2.64 \\
\hline Startup had Angel on board & 0.811 & 0.2255 & -0.75 & 0.957 & 0.3176 & -0.13 & 0.959 & 0.3225 & -0.12 \\
\hline $\begin{array}{l}\text { Startup had VC on board } \\
\text { Financing Characteristics }\end{array}$ & $1.977^{*}$ & 0.9641 & 1.76 & $2.309^{*}$ & 1.1217 & 1.72 & $2.061 * *$ & 0.9743 & 2.13 \\
\hline Total number of financing rounds & & & & $0.629 * * *$ & 0.0841 & -3.47 & $0.624 * * *$ & 0.0812 & -3.62 \\
\hline $\begin{array}{l}\text { Average growth rate of external financing amount } \\
\qquad \underline{\text { Market Conditions }}\end{array}$ & & & & & & & 0.989 & 0.0110 & -0.99 \\
\hline $\begin{array}{l}\text { Local MSCI Index Return on Exit Month } \\
\text { Interaction Variable }\end{array}$ & $0.0004 * *$ & 0.0013 & -2.07 & $0.0004 * *$ & 0.0016 & -2.01 & $0.0005 * *$ & 0.0019 & -1.99 \\
\hline $\begin{array}{l}\text { Startup had VC on board* Startup had joined } \\
\text { incubator/technology park }\end{array}$ & & & & $0.579 * * *$ & 0.2064 & -3.78 & $0.588 * * *$ & 0.2343 & -4.13 \\
\hline Observations & & 251 & & & 251 & & & 251 & \\
\hline No. failed & & 77 & & & 77 & & & 77 & \\
\hline No. competing & & 174 & & & 174 & & & 174 & \\
\hline Wald chi^2 & & 18.13 & & & 28.84 & & & 37.72 & \\
\hline
\end{tabular}


Panel A. (Continued)

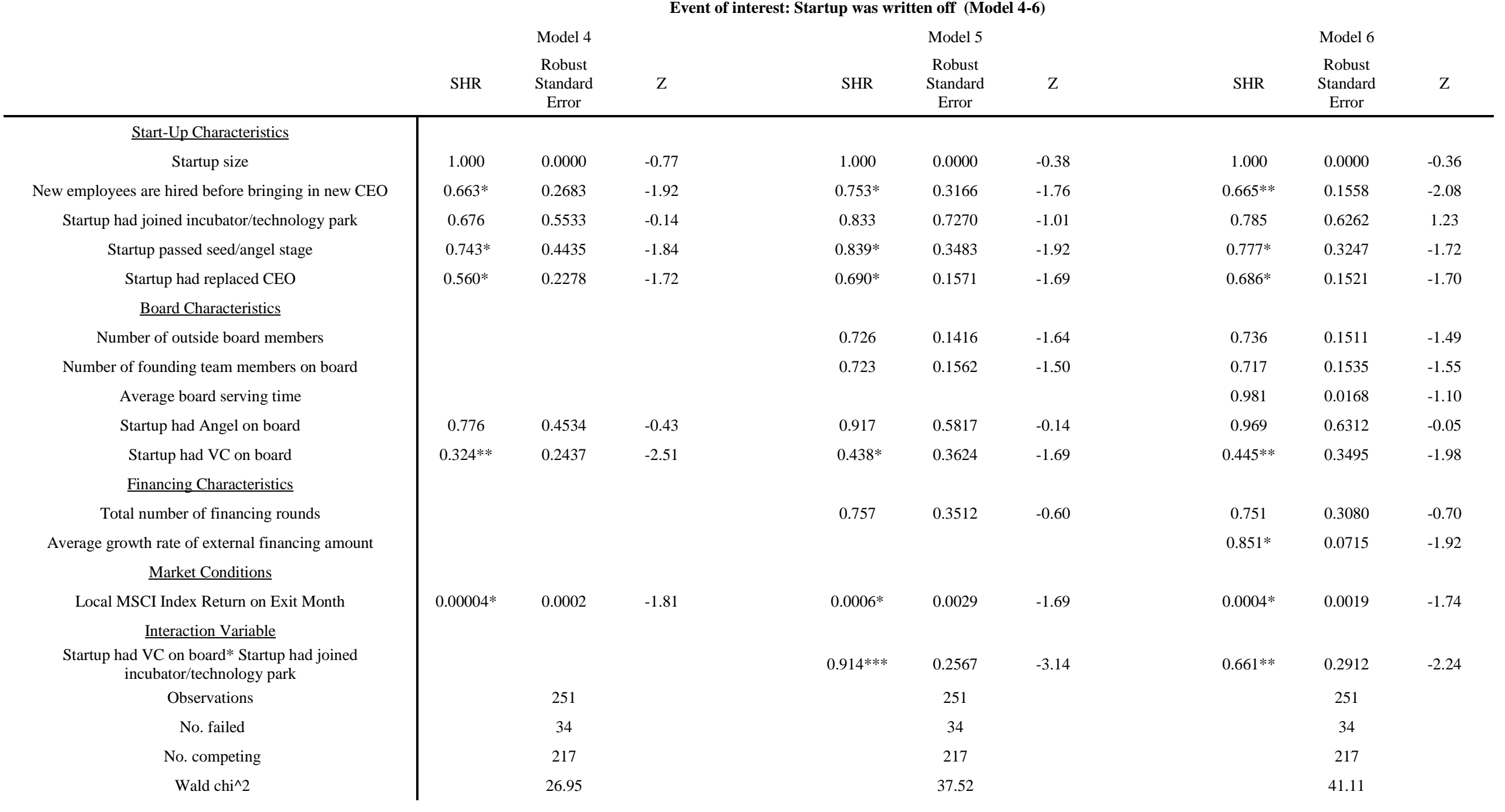


Panel B. Competing Risks Model—Coefficients Estimation

\begin{tabular}{|c|c|c|c|c|c|c|}
\hline & \multicolumn{3}{|c|}{ Startup was acquired (Model 1-3) } & \multicolumn{3}{|c|}{ Startup was written off (Model 4-6) } \\
\hline & Model 1 & Model 2 & Model 3 & Model 4 & Model 5 & Model 6 \\
\hline \multicolumn{7}{|l|}{$\underline{\text { Start-Up Characteristics }}$} \\
\hline Startup size & $\begin{array}{c}5.30 \mathrm{E}-10 \\
(0.29)\end{array}$ & $\begin{array}{c}3.74 \mathrm{E}-09 \\
(0.78)\end{array}$ & $\begin{array}{c}4.43 \mathrm{E}-09 \\
(1.32)\end{array}$ & $\begin{array}{c}-3.10 \mathrm{E}-08 \\
(-0.77)\end{array}$ & $\begin{array}{c}-1.08 \mathrm{E}-08 \\
(-0.38)\end{array}$ & $\begin{array}{c}-1.21 \mathrm{E}-08 \\
(-0.36)\end{array}$ \\
\hline New employees are hired before bringing in new CEO & $\begin{array}{c}0.185^{*} \\
(1.87)\end{array}$ & $\begin{array}{c}0.194 * * \\
(2.25)\end{array}$ & $\begin{array}{c}0.236^{* *} \\
(2.45)\end{array}$ & $\begin{array}{c}-0.423^{*} \\
(-1.92)\end{array}$ & $\begin{array}{c}-0.278^{*} \\
(-1.76)\end{array}$ & $\begin{array}{c}-0.417 * * \\
(-2.08)\end{array}$ \\
\hline Startup had joined incubator/technology park & $\begin{array}{l}0.313^{*} \\
(1.89)\end{array}$ & $\begin{array}{c}0.965^{* *} \\
(2.45)\end{array}$ & $\begin{array}{c}1.056^{* *} \\
(2.54)\end{array}$ & $\begin{array}{l}-0.391 \\
(-0.14)\end{array}$ & $\begin{array}{l}-0.178 \\
(-1.01)\end{array}$ & $\begin{array}{r}-0.258 \\
(1.23)\end{array}$ \\
\hline Startup passed seed/angel stage & $\begin{array}{l}0.124 * \\
(1.66)\end{array}$ & $\begin{array}{l}0.292^{*} \\
(1.93)\end{array}$ & $\begin{array}{c}0.346^{* * *} \\
(2.01)\end{array}$ & $\begin{array}{l}-0.296^{*} \\
(-1.84)\end{array}$ & $\begin{array}{l}-0.173^{*} \\
(-1.92)\end{array}$ & $\begin{array}{c}-0.279^{*} \\
(-1.72)\end{array}$ \\
\hline Startup had replaced CEO & $\begin{array}{c}0.173^{*} \\
(1.92)\end{array}$ & $\begin{array}{c}0.179 * \\
(1.71)\end{array}$ & $\begin{array}{c}0.278^{*} \\
(1.84)\end{array}$ & $\begin{array}{l}-0.644 * \\
(-1.72)\end{array}$ & $\begin{array}{l}-0.527 * \\
(-1.69)\end{array}$ & $\begin{array}{c}-0.534 * \\
(-1.70)\end{array}$ \\
\hline \multicolumn{7}{|l|}{ Board Characteristics } \\
\hline Number of outside board members & & $\begin{array}{c}0.185 * \\
(1.95)\end{array}$ & $\begin{array}{c}0.196^{* * *} \\
(2.06)\end{array}$ & & $\begin{array}{l}-0.296 \\
(-1.64)\end{array}$ & $\begin{array}{l}-0.284 \\
(-1.49)\end{array}$ \\
\hline Number of founding team members on board & & $\begin{array}{l}0.224 * \\
(1.73)\end{array}$ & $\begin{array}{c}0.229^{*} \\
(1.81)\end{array}$ & & $\begin{array}{l}-0.305 \\
(-1.50)\end{array}$ & $\begin{array}{l}-0.342 \\
(-1.55)\end{array}$ \\
\hline Average board serving time & & & $\begin{array}{c}-0.0233 * * * \\
(-2.64)\end{array}$ & & & $\begin{array}{l}-0.0169 \\
(-1.10)\end{array}$ \\
\hline Startup had Angel on board & $\begin{array}{l}-0.210 \\
(-0.75)\end{array}$ & $\begin{array}{l}-0.0436 \\
(-0.13)\end{array}$ & $\begin{array}{c}-0.0410 \\
(-0.12)\end{array}$ & $\begin{array}{l}-0.253 \\
(-0.43)\end{array}$ & $\begin{array}{c}-0.0856 \\
(-0.14)\end{array}$ & $\begin{array}{l}-0.0308 \\
(-0.05)\end{array}$ \\
\hline Startup had VC on board & $\begin{array}{l}0.682^{*} \\
(1.76)\end{array}$ & $\begin{array}{c}0.837^{*} \\
(1.72)\end{array}$ & $\begin{array}{c}0.723 * * \\
(2.13)\end{array}$ & $\begin{array}{c}-1.126^{* *} \\
(-2.51)\end{array}$ & $\begin{array}{l}-0.823 * \\
(-1.69)\end{array}$ & $\begin{array}{c}-0.810^{* *} \\
(-1.98)\end{array}$ \\
\hline $\begin{array}{c}\text { Financing Characteristics } \\
\text { Total number of financing rounds }\end{array}$ & & $\begin{array}{c}-0.467 * * * \\
(-3.47)\end{array}$ & $\begin{array}{c}-0.478 * * * \\
(-3.62)\end{array}$ & & $\begin{array}{l}-0.271 \\
(-0.60)\end{array}$ & $\begin{array}{l}-0.278 \\
(-0.70)\end{array}$ \\
\hline Average growth rate of external financing amount & & & $\begin{array}{c}-0.0126 \\
(-0.99)\end{array}$ & & & $\begin{array}{l}-0.152^{*} \\
(-1.92)\end{array}$ \\
\hline Market Conditions & & & & & & \\
\hline Local MSCI Index Return on Exit Month & $\begin{array}{c}-7.955^{* *} \\
(-2.07)\end{array}$ & $\begin{array}{c}-7.807 * * \\
(-2.01)\end{array}$ & $\begin{array}{c}-7.627 * * \\
(-1.99)\end{array}$ & $\begin{array}{l}-8.167 * \\
(-1.81)\end{array}$ & $\begin{array}{l}-6.847 * \\
(-1.69)\end{array}$ & $\begin{array}{l}-7.460^{*} \\
(-1.74)\end{array}$ \\
\hline Interaction Variable & & & & & & \\
\hline Number of Angel/VC on board* Startup had joined incubator/technology park & & $\begin{array}{c}-0.548 * * * \\
(-3.78)\end{array}$ & $\begin{array}{c}-0.531 * * * \\
(-4.13)\end{array}$ & & $\begin{array}{c}-0.0897 * * * * \\
(-3.14)\end{array}$ & $\begin{array}{c}-0.420 * * \\
(-2.24)\end{array}$ \\
\hline Observations & 251 & 251 & 251 & 251 & 251 & 251 \\
\hline No. failed & 77 & 77 & 77 & 34 & 34 & 34 \\
\hline No. competing & 174 & 174 & 174 & 217 & 217 & 217 \\
\hline Wald chi^2 & 18.13 & 28.84 & 37.72 & 26.95 & 37.52 & 41.11 \\
\hline
\end{tabular}


Table 5. Competing Risks Analysis on CEO Replacement

This table shows the influence of different firm characters on CEO replacement using competing risks regressions. Panel A. presents the estimated subhazard ratio (SHR) of different firm characters for startup CEO replacement during the sample period from January 2007 to May 2014. Subhazard ratio greater than 1stands for positive influence on CEO replacement; smaller than 1, negative influence. Panel B. presents the coefficients of the same set of competing risks regressions. T values are shown in brackets. *, **,*** Significant at the $10 \%, 5 \%$, and $1 \%$ levels, respectively.

Panel A. Competing Risks Model--Subhazard Ratio Estimation

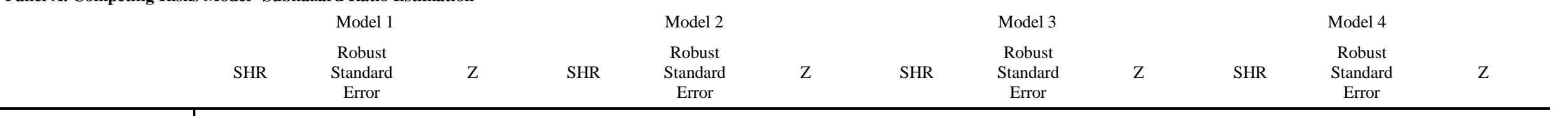

\begin{tabular}{|c|c|c|c|c|c|c|c|c|c|c|c|c|}
\hline & & Error & & & Error & & & Error & & & Error & \\
\hline \multicolumn{13}{|l|}{$\underline{\text { Start-Up Characteristics }}$} \\
\hline Number of all current key employees & & & & $0.857 * * *$ & 0.0355 & -3.70 & $0.865^{* * *}$ & 0.0378 & -3.31 & $0.837 * * *$ & 0.0482 & -3.09 \\
\hline Number of executive managers & & & & $1.208 * * *$ & 0.0511 & 4.46 & $1.233 * * *$ & 0.0553 & 4.67 & $1.254 * * *$ & 0.0674 & 4.21 \\
\hline $\begin{array}{l}\text { Startup had joined incubator/technology } \\
\text { park }\end{array}$ & & & & 0.551 & 0.4448 & -0.74 & 0.928 & 0.8563 & -1.25 & 0.772 & 0.8311 & -1.09 \\
\hline Startup had a board of directors & $7.809^{* * *}$ & 4.9634 & 3.23 & $7.524 * * *$ & 4.9400 & 3.07 & $10.576^{* * *}$ & 7.3833 & 3.38 & $10.731 * * *$ & 8.3178 & 3.06 \\
\hline \multicolumn{13}{|l|}{$\underline{\text { Board Characteristics }}$} \\
\hline Number of outside board members & & & & & & & $0.843^{* *}$ & 0.0663 & -2.17 & $0.878 *$ & 0.0681 & -1.68 \\
\hline Startup had Angel on board & 0.838 & 0.2501 & -0.59 & 0.939 & 0.2892 & -0.21 & 0.904 & 0.3022 & -0.31 & 0.720 & 0.2852 & -0.83 \\
\hline Startup had VC on board & $2.374 *$ & 1.3144 & 1.92 & $1.931 *$ & 1.0729 & 1.84 & $2.525^{*}$ & 1.3775 & 1.70 & $1.783 *$ & 0.9769 & 1.85 \\
\hline Startup had inside chairman & & & & & & & 1.255 & 0.3937 & 0.73 & & & \\
\hline Startup had founder chairman & & & & & & & & & & 0.648 & 0.2497 & -1.13 \\
\hline Financing Characteristics & & & & & & & & & & & & \\
\hline $\begin{array}{c}\text { Average growth rate of external financing } \\
\text { amount }\end{array}$ & & & & & & & $0.749 * *$ & 0.0866 & -2.50 & $0.788^{* *}$ & 0.1024 & -2.26 \\
\hline \multicolumn{13}{|l|}{ Market Conditions } \\
\hline $\begin{array}{l}\text { Local MSCI Index Return on CEO } \\
\text { Replacement Month }\end{array}$ & $2.08 \mathrm{e}^{\wedge}-6^{* * *}$ & $7.97 e^{\wedge}-6$ & -3.41 & $5.96 \mathrm{e}-6^{* * *}$ & $2.14 \mathrm{e}^{\wedge}-6$ & -3.35 & $1.62 \mathrm{e}^{\wedge}-7 * * *$ & $6.63 \mathrm{e}^{\wedge}-7$ & -3.82 & $3.98 \mathrm{e}^{\wedge}-7 * * *$ & $1.69 \mathrm{e}^{\wedge}-6$ & -3.47 \\
\hline \multicolumn{13}{|l|}{ Interaction Variable } \\
\hline $\begin{array}{l}\text { Startup had VC on board } * \text { Startup had } \\
\text { joined incubator/technology park }\end{array}$ & & & & & & & $1.163 * * *$ & 1.4403 & 9.42 & $1.767 * * *$ & 1.3888 & 8.94 \\
\hline Observations & & 251 & & & 251 & & & 251 & & & 251 & \\
\hline No. failed & & 51 & & & 51 & & & 51 & & & 51 & \\
\hline No. competing & & 200 & & & 200 & & & 200 & & & 200 & \\
\hline Wald chi^2 & & 24.32 & & & 48.57 & & & 60.55 & & & 41.47 & \\
\hline
\end{tabular}

Panel A. (Continued) 


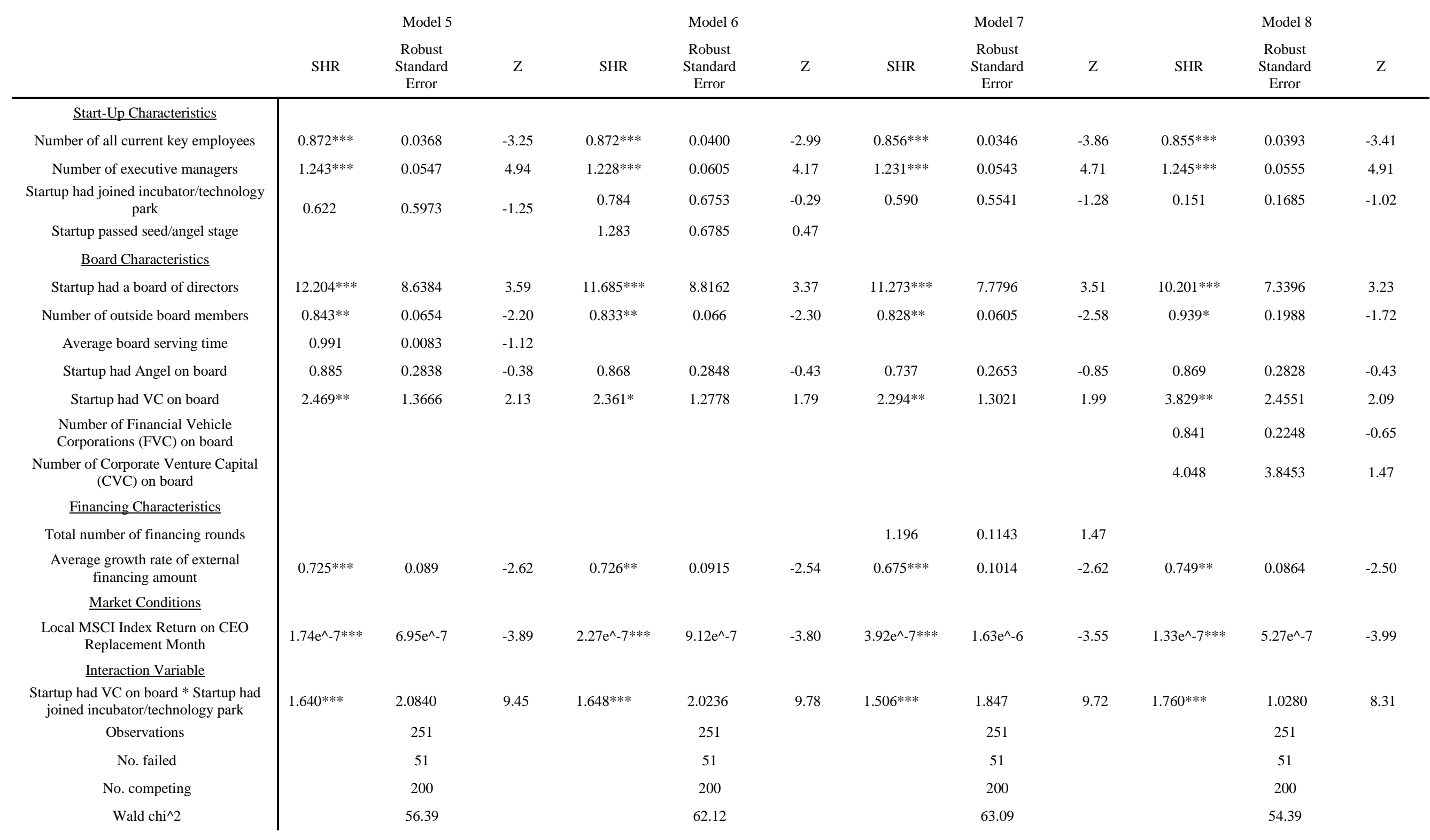


Panel B. Competing Risks Model-Coefficients Estimation

Event of interest: Startup had CEO replacement

\begin{tabular}{|c|c|c|c|c|c|c|c|c|}
\hline & Model 1 & Model 2 & Model 3 & Model 4 & Model 5 & Model 6 & Model 7 & Model 8 \\
\hline Start-Up Characteristics & & & & & & & & \\
\hline Number of all current key employees & & $\begin{array}{c}-0.157 * * * \\
(-3.70)\end{array}$ & $\begin{array}{c}-0.145 * * * \\
(-3.31)\end{array}$ & $\begin{array}{c}-0.178 * * * \\
(-3.09)\end{array}$ & $\begin{array}{c}-0.137 * * * \\
(-3.25)\end{array}$ & $\begin{array}{c}-0.137 * * * \\
(-2.99)\end{array}$ & $\begin{array}{c}-0.156 * * * \\
(-3.86)\end{array}$ & $\begin{array}{c}-0.157 * * * \\
(-3.41)\end{array}$ \\
\hline Number of executive managers & & $\begin{array}{c}0.205^{* * *} \\
(4.46)\end{array}$ & $\begin{array}{l}0.213 * * * \\
(4.67)\end{array}$ & $\begin{array}{l}0.226 * * * \\
(4.21)\end{array}$ & $\begin{array}{l}0.217 * * * \\
(4.94)\end{array}$ & $\begin{array}{l}0.209 * * * \\
(4.17)\end{array}$ & $\begin{array}{c}0.211 * * * \\
(4.71)\end{array}$ & $\begin{array}{l}0.219 * * * \\
(4.91)\end{array}$ \\
\hline Startup had joined incubator/technology park & & $\begin{array}{l}-0.596 \\
(-0.74)\end{array}$ & $\begin{array}{l}-0.136 \\
(-1.25)\end{array}$ & $\begin{array}{l}-0.315 \\
(-1.09)\end{array}$ & $\begin{array}{l}-0.412 \\
(-1.25)\end{array}$ & $\begin{array}{l}-0.248 \\
(-0.29)\end{array}$ & $\begin{array}{l}-0.523 \\
(-1.28)\end{array}$ & $\begin{array}{l}-1.036 \\
(-1.02)\end{array}$ \\
\hline Startup passed seed/angel stage & & & & & & $\begin{array}{l}0.249 \\
(0.47)\end{array}$ & & \\
\hline Startup had a board of directors & $\begin{array}{l}2.174 * * * \\
(3.23)\end{array}$ & $\begin{array}{l}2.169 * * * \\
(3.07)\end{array}$ & $\begin{array}{l}2.728 * * * \\
(3.38)\end{array}$ & $\begin{array}{l}2.735 * * * \\
(3.06)\end{array}$ & $\begin{array}{l}2.870 * * * \\
(3.59)\end{array}$ & $\begin{array}{l}2.769 * * * \\
(3.37)\end{array}$ & $\begin{array}{l}2.711 * * * \\
(3.51)\end{array}$ & $\begin{array}{l}2.654 * * * \\
(3.23)\end{array}$ \\
\hline$\frac{\text { Board Characteristics }}{\text { Number of outside board members }}$ & & & $\begin{array}{c}-0.171 * * \\
(-2.17)\end{array}$ & $\begin{array}{c}-0.130 * \\
(-1.68)\end{array}$ & $\begin{array}{c}-0.171 * * \\
(-2.20)\end{array}$ & $\begin{array}{c}-0.182 * * \\
(-2.30)\end{array}$ & $\begin{array}{c}-0.188 * * * \\
(-2.58)\end{array}$ & $\begin{array}{c}-0.0633 * \\
(-1.72)\end{array}$ \\
\hline Average board serving time & & & & & $\begin{array}{c}-0.0094 \\
(-1.12)\end{array}$ & & & \\
\hline Startup had Angel on board & $\begin{array}{l}-0.332 \\
(-0.59)\end{array}$ & $\begin{array}{l}-0.291 \\
(-0.21)\end{array}$ & $\begin{array}{l}-0.101 \\
(-0.31)\end{array}$ & $\begin{array}{l}-0.328 \\
(-0.83)\end{array}$ & $\begin{array}{l}-0.122 \\
(-0.38)\end{array}$ & $\begin{array}{l}-0.142 \\
(-0.43)\end{array}$ & $\begin{array}{l}-0.305 \\
(-0.85)\end{array}$ & $\begin{array}{l}-0.140 \\
(-0.43)\end{array}$ \\
\hline Startup had VC on board & $\begin{array}{c}0.926^{*} \\
(1.92)\end{array}$ & $\begin{array}{l}0.770^{*} \\
(1.84)\end{array}$ & $\begin{array}{l}1.061 * \\
(1.70)\end{array}$ & $\begin{array}{c}0.578^{*} \\
(1.85)\end{array}$ & $\begin{array}{c}0.954^{* *} \\
(2.13)\end{array}$ & $\begin{array}{c}0.859^{*} \\
(1.79)\end{array}$ & $\begin{array}{c}0.830 * * \\
(1.99)\end{array}$ & $\begin{array}{l}1.342 * * \\
(2.09)\end{array}$ \\
\hline Startup had inside chairman & & & $\begin{array}{l}0.227 \\
(0.73)\end{array}$ & & & & & \\
\hline Startup had founder chairman & & & & $\begin{array}{l}-0.434 \\
(-1.13)\end{array}$ & & & & \\
\hline Number of Financial Vehicle Corporations (FVC) on board & & & & & & & & $\begin{array}{l}-0.173 \\
(-0.65)\end{array}$ \\
\hline $\begin{array}{c}\text { Number of Corporate Venture Capital (CVC) on board } \\
\text { Financing Characteristics }\end{array}$ & & & & & & & & $\begin{array}{l}1.398 \\
(1.47)\end{array}$ \\
\hline Total number of financing rounds & & & & & & & $\begin{array}{l}0.179 \\
(1.47)\end{array}$ & \\
\hline Average growth rate of external financing amount & & & $\begin{array}{c}-0.311^{* *} \\
(-2.50)\end{array}$ & $\begin{array}{c}-0.289 * * \\
(-2.26)\end{array}$ & $\begin{array}{c}-0.322 * * * \\
(-2.62)\end{array}$ & $\begin{array}{c}-0.320 * * \\
(-2.54)\end{array}$ & $\begin{array}{c}-0.393 * * * \\
(-2.62)\end{array}$ & $\begin{array}{c}-0.311 * * \\
(-2.50)\end{array}$ \\
\hline$\underline{\text { Market Conditions }}$ & & & & & & & & \\
\hline Local MSCI Index Return on CEO Replacement Month & $-13.08 * * *$ & $-12.24 * * *$ & $-15.64 * * *$ & $-14.74 * * *$ & $-15.57 * * *$ & $-15.30 * * *$ & $-14.75 * * *$ & $-15.84 * * *$ \\
\hline Interaction Variable & $(-3.41)$ & $(-3.35)$ & $(-3.82)$ & $(-3.47)$ & $(-3.89)$ & $(-3.80)$ & $(-3.55)$ & $(-3.99)$ \\
\hline $\begin{array}{l}\text { Startup had VC on board } * \text { Startup had joined } \\
\text { incubator/technology park }\end{array}$ & & & $0.179 * * *$ & $0.564 * * *$ & $0.465 * * *$ & $0.473 * * *$ & $0.396 * * *$ & $0.558 * * *$ \\
\hline Observations & 251 & 251 & $\begin{array}{c}(9.42) \\
251\end{array}$ & $\begin{array}{l}(8.94) \\
251\end{array}$ & $\begin{array}{l}(9.45) \\
251\end{array}$ & $\begin{array}{c}(9.78) \\
251\end{array}$ & $\begin{array}{c}(9.72) \\
251\end{array}$ & $\begin{array}{c}(8.31) \\
251\end{array}$ \\
\hline No. failed & 51 & 51 & 51 & 51 & 51 & 51 & 51 & 51 \\
\hline No. competing & 200 & 200 & 200 & 200 & 200 & 200 & 200 & 200 \\
\hline Wald chi^ 2 & 24.32 & 48.57 & 60.55 & 41.47 & 56.39 & 62.12 & 65.29 & 54.39 \\
\hline
\end{tabular}




\section{Figure 1. The Influence of Venture Capital on Startup Exit}

This figure shows the influence of VC on startups' operational outcome using cumulative incidence function (CIF). Cumulative incidence depicts the probability of an event occurs before given time. The figure is based on competing risks analysis using Model 3(exit through acquisition) and Model 6(exit through write-off) in Table 4 Panel A.
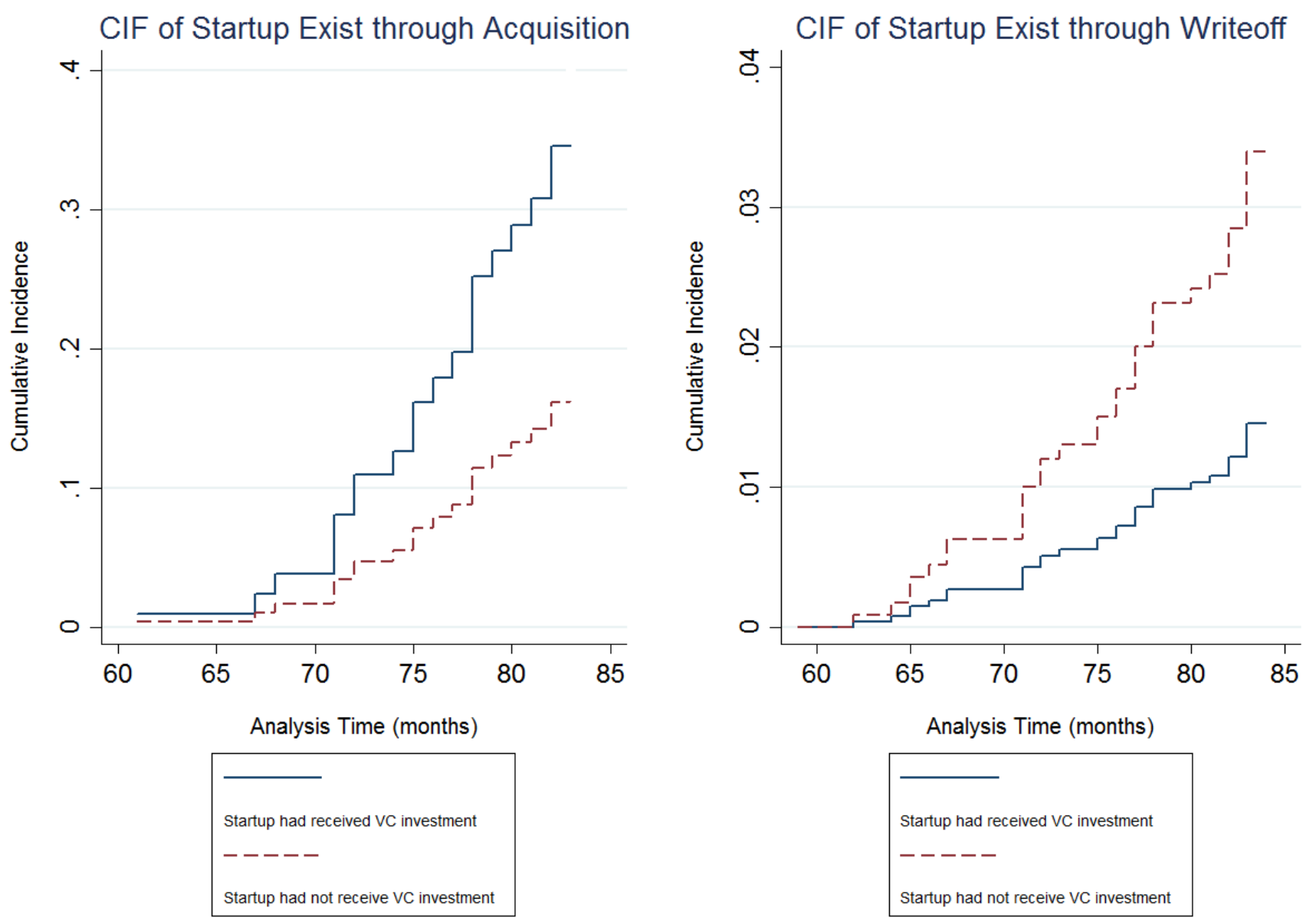
Figure 2. The Influence of CEO replacement on Startup Exit

This figure shows the influence of CEO replacement on startups' operational outcome using cumulative incidence function (CIF). Cumulative incidence depicts the probability of an event occurs before given time. The figure is based on competing risks analysis using Model 3(exit through acquisition) and Model 6(exit through write-off) in Table 4 Panel A.
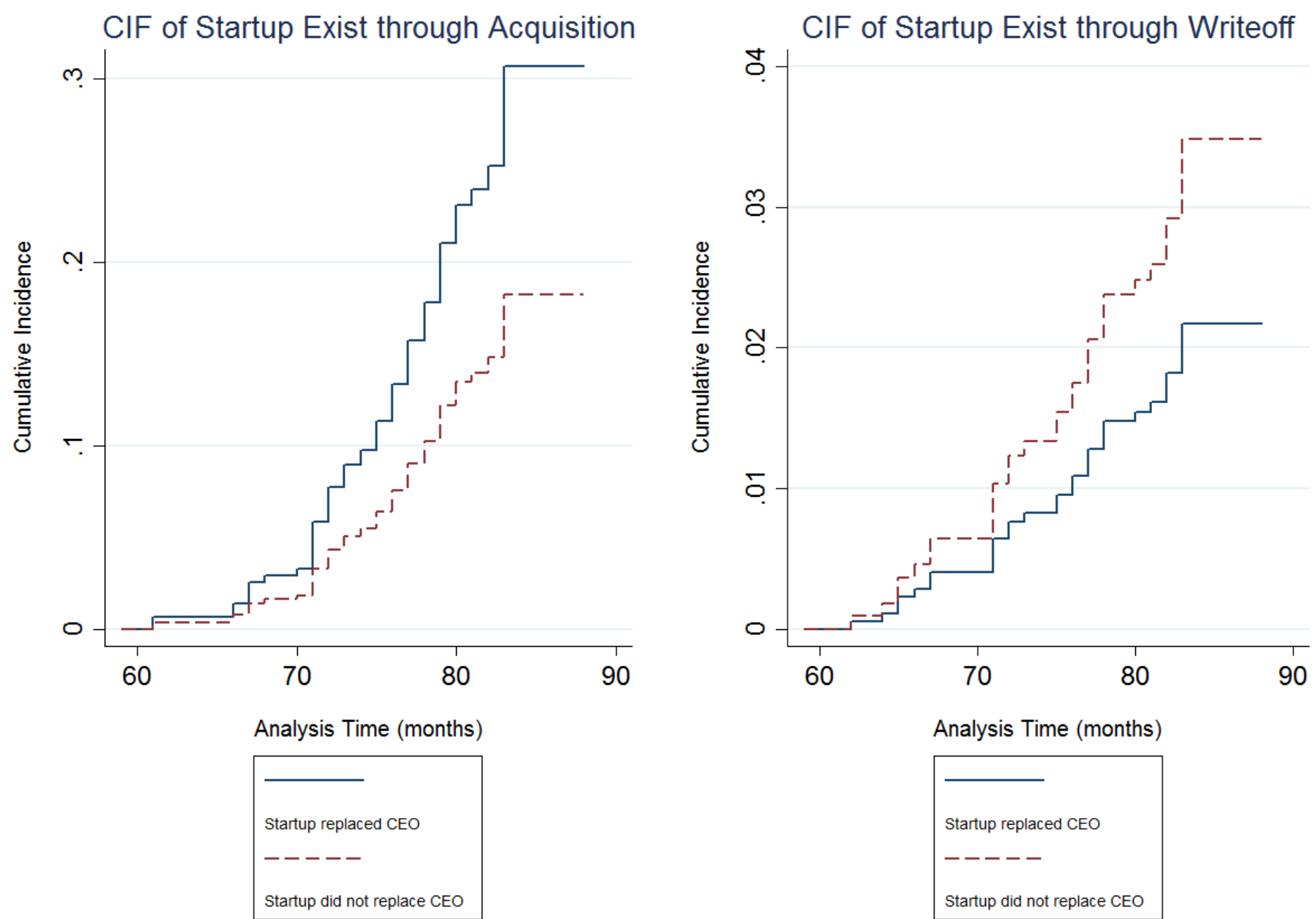
Figure 3. The Influence of Incubator/Technology Park Experience on Startup Exit

This figure shows the influence of incubator/technology park experience on startups' operational outcome using cumulative incidence function (CIF). Cumulative incidence depicts the probability of an event occurs before given time. The figure is based on competing risks analysis using Model 3(exit through acquisition) and Model 6(exit through write-off) in Table 4 Panel A.
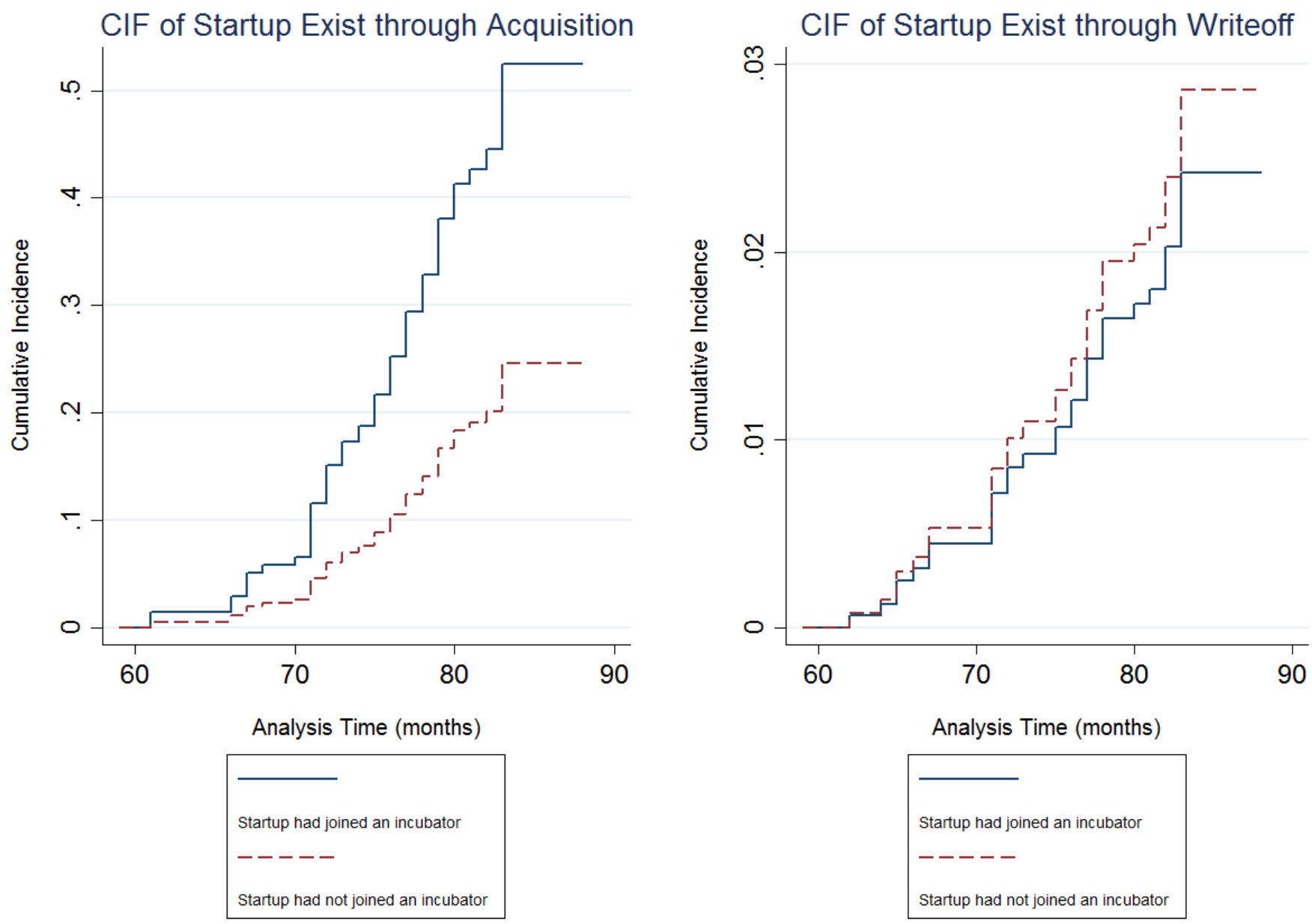
Figure 4. Influences on CEO Replacement

This figure shows the influence of VC, management, employee and board on CEO replacement using cumulative incidence function (CIF). Cumulative incidence depicts the probability of an event occurs before given time. The figure is based on competing risks analysis using Model 3 in Table 5 Panel A.
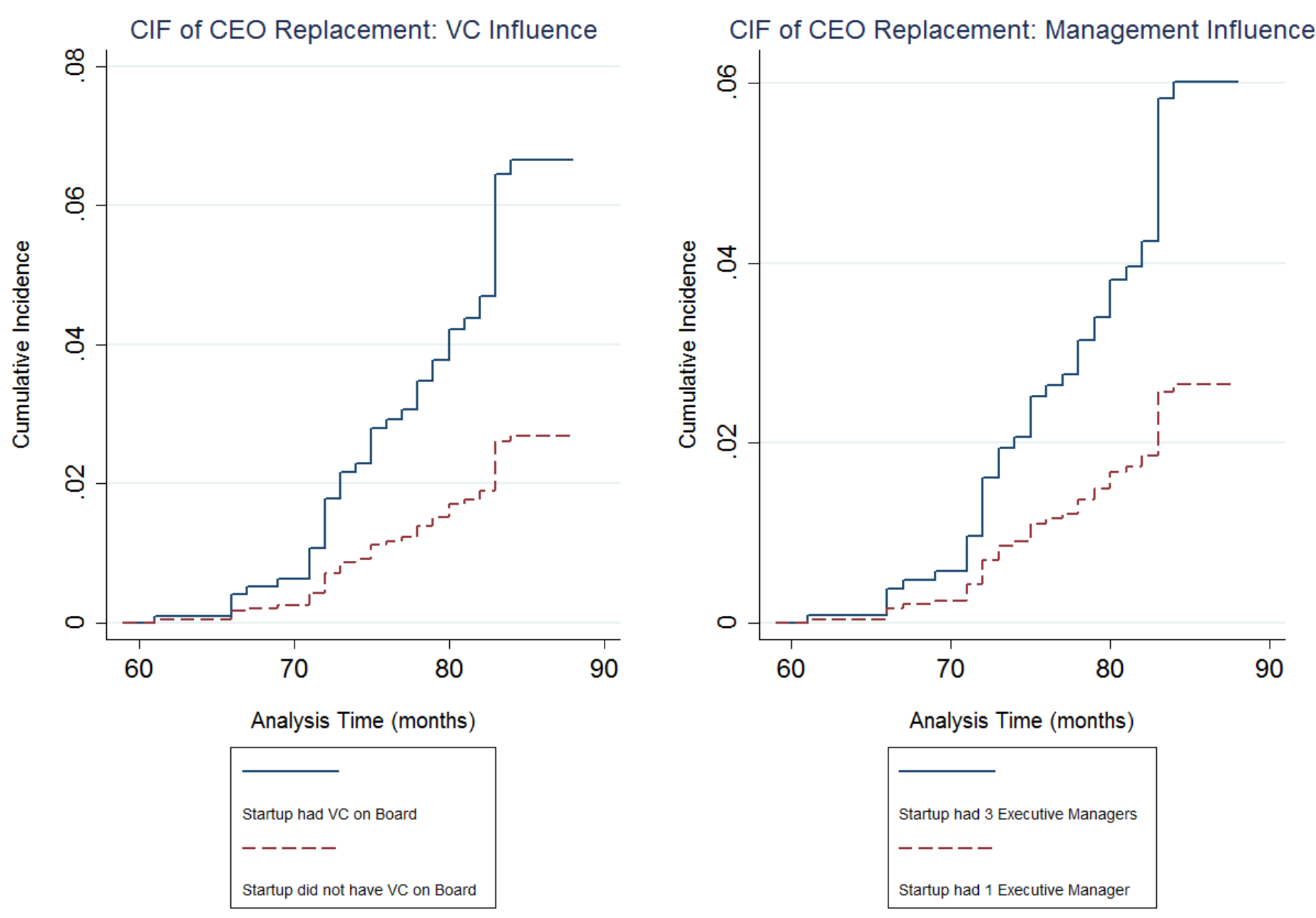


\section{Figure 4 (Continued)}
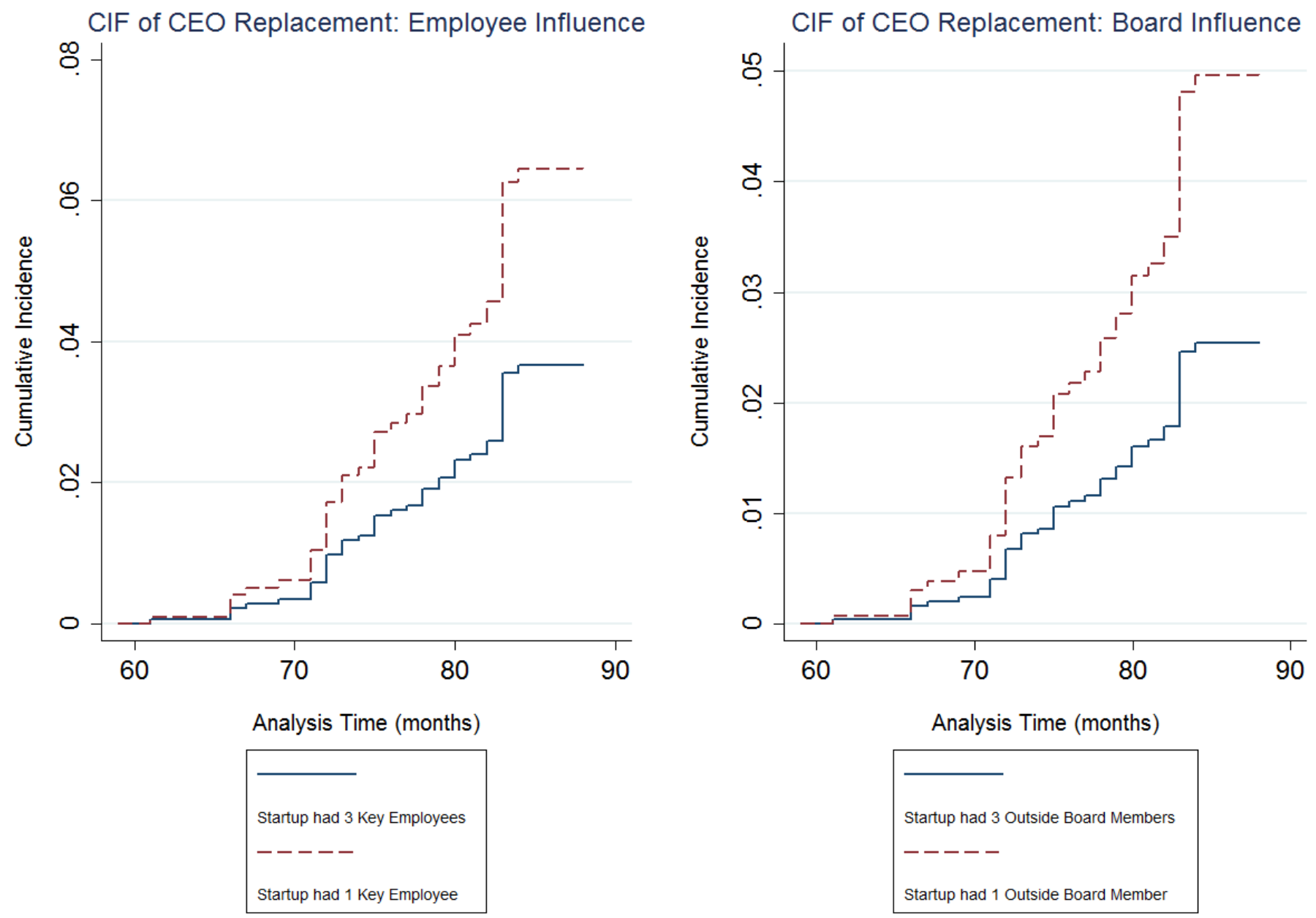


\section{Appendix}

In this appendix, we present the results of robustness checks for Table 4 and Table 5 using logit regressions. For startup outcome analysis, exist year fixed effect is included in the analysis; for CEO replacement analysis, replacement year fixed effect is included in the analysis. 
Table A.I. Logit Analysis on Startup Outcome

This table presents the logit regression results of startup outcome analysis. The dependent variable equals 1 if the outcome of interest occurs and 0 otherwise. T values are shown in brackets. *, $* *, * * *$ Significant at the $10 \%, 5 \%$, and $1 \%$ levels, respectively.

\begin{tabular}{|c|c|c|c|c|c|c|}
\hline & \multicolumn{3}{|c|}{ Startup was acquired (Model 1-3) } & \multicolumn{3}{|c|}{ Startup was written off (Model 4-6) } \\
\hline & Model 1 & Model 2 & Model 3 & Model 4 & Model 5 & Model 6 \\
\hline \multicolumn{7}{|l|}{ Start-Up Characteristics } \\
\hline Startup size & $\begin{array}{c}-3.18 \mathrm{E}-11 \\
(-0.10)\end{array}$ & $\begin{array}{c}5.55 \mathrm{E}-10 \\
(1.56)\end{array}$ & $\begin{array}{c}6.20 \mathrm{e}-10^{*} \\
(1.75)\end{array}$ & $\begin{array}{c}-1.05 \mathrm{E}-10 \\
(-0.45)\end{array}$ & $\begin{array}{c}-4.39 \mathrm{E}-12 \\
(-0.02)\end{array}$ & $\begin{array}{c}9.02 \mathrm{E}-13 \\
(0.03)\end{array}$ \\
\hline New employees are hired before bringing in new CEO & $\begin{array}{c}-0.03 \\
(-0.49)\end{array}$ & $\begin{array}{c}-0.0365 \\
(-0.59)\end{array}$ & $\begin{array}{r}-0.0391 \\
(-0.64)\end{array}$ & $\begin{array}{c}-0.0296^{*} \\
(-1.66)\end{array}$ & $\begin{array}{c}-0.0149 * * \\
(-2.32)\end{array}$ & $\begin{array}{c}-0.0160 * * \\
(-2.35)\end{array}$ \\
\hline Startup had joined incubator/technology park & & $\begin{array}{c}0.210^{* *} \\
(2.12)\end{array}$ & $\begin{array}{c}0.225^{* *} \\
(2.17)\end{array}$ & & $\begin{array}{c}-0.0366 \\
(-0.50)\end{array}$ & $\begin{array}{c}-0.0254 \\
(-0.33)\end{array}$ \\
\hline Startup passed seed/angel stage & $\begin{array}{c}0.109 * \\
(1.69)\end{array}$ & $\begin{array}{c}0.156^{* *} \\
(2.08)\end{array}$ & $\begin{array}{c}0.150^{* *} \\
(2.02)\end{array}$ & $\begin{array}{c}-0.0918 * \\
(-1.79)\end{array}$ & $\begin{array}{c}-0.0632 * * \\
(-2.14)\end{array}$ & $\begin{array}{c}-0.0618^{* *} \\
(-2.11)\end{array}$ \\
\hline Startup had replaced CEO & $\begin{array}{c}0.108^{*} \\
(1.83)\end{array}$ & $\begin{array}{c}0.129^{*} \\
(1.76)\end{array}$ & $\begin{array}{l}0.139^{*} \\
(1.91)\end{array}$ & $\begin{array}{c}-0.115^{* *} \\
(-2.15)\end{array}$ & $\begin{array}{c}-0.101^{*} \\
(-1.87)\end{array}$ & $\begin{array}{c}-0.100^{*} \\
(-1.84)\end{array}$ \\
\hline \multicolumn{7}{|l|}{ Board Characteristics } \\
\hline Number of outside board members & & $\begin{array}{c}0.0433 * * \\
(2.25)\end{array}$ & $\begin{array}{c}0.0458 * * \\
(2.40)\end{array}$ & & $\begin{array}{c}-0.0184 \\
(-1.29)\end{array}$ & $\begin{array}{c}-0.0183 \\
(-1.28)\end{array}$ \\
\hline Number of founding team members on board & & $\begin{array}{c}0.0529^{*} \\
(1.94)\end{array}$ & $\begin{array}{c}0.0491^{*} \\
(1.81)\end{array}$ & & $\begin{array}{c}-0.0375^{*} \\
(-1.86)\end{array}$ & $\begin{array}{c}-0.0379^{*} \\
(-1.87)\end{array}$ \\
\hline Average board serving time & & & $\begin{array}{c}-0.00545^{* *} \\
(-2.49)\end{array}$ & & & $\begin{array}{c}-0.000356 \\
(-0.22)\end{array}$ \\
\hline Startup had Angel on board & $\begin{array}{c}-0.0308 \\
(-0.52)\end{array}$ & $\begin{array}{c}-0.0238 \\
(-0.38)\end{array}$ & $\begin{array}{c}-0.0222 \\
(-0.35)\end{array}$ & $\begin{array}{r}-0.0285 \\
(-0.61)\end{array}$ & $\begin{array}{r}-0.0161 \\
(-0.33)\end{array}$ & $\begin{array}{r}-0.0189 \\
(-0.38)\end{array}$ \\
\hline Startup had VC on board & $\begin{array}{l}0.121 * * \\
(2.27)\end{array}$ & $\begin{array}{c}0.123 * * \\
(2.23)\end{array}$ & $\begin{array}{c}0.118^{* *} \\
(1.98)\end{array}$ & $\begin{array}{c}-0.149^{* *} \\
(-2.00)\end{array}$ & $\begin{array}{c}-0.165^{* *} \\
(-2.13)\end{array}$ & $\begin{array}{c}-0.163^{* *} \\
(-2.10)\end{array}$ \\
\hline \multicolumn{7}{|l|}{ Financing Characteristics } \\
\hline Total number of financing rounds & & $\begin{array}{c}-0.105 * * * \\
(-3.69)\end{array}$ & $\begin{array}{c}-0.103 * * * \\
(-3.65)\end{array}$ & & $\begin{array}{c}-0.0125 \\
(-0.59)\end{array}$ & $\begin{array}{c}-0.0124 \\
(-0.59)\end{array}$ \\
\hline Average growth rate of external financing amount & & & $\begin{array}{c}-0.00195 \\
(-1.01)\end{array}$ & & & $\begin{array}{c}-0.000739 \\
(-0.51)\end{array}$ \\
\hline Market Conditions & & & & & & \\
\hline $\begin{array}{l}\text { Local MSCI Index Return on Exit Month } \\
\text { Interaction Variable }\end{array}$ & $\begin{array}{l}-0.617 \\
(-0.65)\end{array}$ & $\begin{array}{l}-0.908 \\
(-0.95)\end{array}$ & $\begin{array}{l}-0.88^{*} \\
(-1.92)\end{array}$ & $\begin{array}{l}-0.276 \\
(-0.37)\end{array}$ & $\begin{array}{r}-0.542 * \\
(-1.73)\end{array}$ & $\begin{array}{l}-0.501 \\
(-1.60)\end{array}$ \\
\hline Startup had VC on board * Startup had joined incubator & & $\begin{array}{c}-0.0448 * * \\
(-2.25)\end{array}$ & $\begin{array}{c}-0.0507 * * \\
(-2.18)\end{array}$ & & $\begin{array}{c}-0.0727 * * \\
(-2.32)\end{array}$ & $\begin{array}{c}-0.0812^{*} \\
(-1.78)\end{array}$ \\
\hline Exit Year Fixed Effect & Yes & Yes & Yes & Yes & Yes & Yes \\
\hline Constant & $\begin{array}{c}0.175^{* * * *} \\
(2.95)\end{array}$ & $\begin{array}{c}0.161^{* *} \\
(1.99)\end{array}$ & $\begin{array}{c}0.442 * * * \\
(3.19)\end{array}$ & $\begin{array}{l}0.310^{* * * *} \\
(7.25)\end{array}$ & $\begin{array}{l}0.396^{* * * *} \\
(6.62)\end{array}$ & $\begin{array}{c}0.414 * * * \\
(3.99)\end{array}$ \\
\hline Observations & 251 & 251 & 251 & 251 & 251 & 251 \\
\hline $\mathrm{R}$-squared & 0.032 & 0.106 & 0.131 & 0.093 & 0.112 & 0.113 \\
\hline $\mathrm{F}$ & $4.049 * * *$ & $5.177 * * *$ & $5.263 * * *$ & $5.013 * * *$ & $6.380^{* * *}$ & $9.772 * * *$ \\
\hline
\end{tabular}


Table A.II. Logit Analysis on CEO Replacement

This table presents the logit regression results of startup CEO replacement. The dependent variable equals 1 if a CEO is replaced and 0 otherwise. T values are shown in brackets. *, **, *** Significant at the $10 \%, 5 \%$, and $1 \%$ levels, respectively.

\begin{tabular}{|c|c|c|c|c|c|c|c|c|}
\hline & Model 1 & Model 2 & Model 3 & Model 4 & Model 5 & Model 6 & Model 7 & Model 8 \\
\hline Start-Up Characteristics & & & & & & & & \\
\hline Number of all current key employees & & $\begin{array}{r}-0.0047 \\
(-1.51)\end{array}$ & $\begin{array}{c}-0.00490 * \\
(-1.69)\end{array}$ & $\begin{array}{c}-0.000712 * \\
(-2.20)\end{array}$ & $\begin{array}{l}-0.0051 \\
(-1.61)\end{array}$ & $\begin{array}{c}-0.00502^{*} \\
(-1.72)\end{array}$ & $\begin{array}{c}-0.00358^{* *} \\
(-2.12)\end{array}$ & $\begin{array}{c}-0.00450^{*} \\
(-1.85)\end{array}$ \\
\hline Number of executive managers & & $\begin{array}{c}0.0000734 * * \\
(2.03)\end{array}$ & $\begin{array}{c}0.000276^{* * * *} \\
(3.10)\end{array}$ & $\begin{array}{c}0.00108^{* * *} \\
(2.34)\end{array}$ & $\begin{array}{c}0.0000741 \text { **** } \\
(3.09)\end{array}$ & $\begin{array}{c}0.000435 * * * \\
(3.15)\end{array}$ & $\begin{array}{c}0.0000551 \text { *** } \\
(3.02)\end{array}$ & $\begin{array}{c}0.000406^{* * * *} \\
(3.14)\end{array}$ \\
\hline Startup has joined incubator/technology park & & $\begin{array}{c}-0.0196 \\
(-0.83)\end{array}$ & $\begin{array}{c}-0.00381 \\
(-0.08)\end{array}$ & $\begin{array}{c}-0.00302 \\
(-0.06)\end{array}$ & $\begin{array}{c}-0.00385 \\
(-0.08)\end{array}$ & $\begin{array}{c}-0.00535 \\
(-0.11)\end{array}$ & $\begin{array}{c}-0.0126 \\
(-0.26)\end{array}$ & $\begin{array}{c}-0.00138 \\
(-0.03)\end{array}$ \\
\hline Startup passed seed/angel stage & & & & & & $\begin{array}{r}0.0177 \\
(0.82)\end{array}$ & & \\
\hline Board Characteristics & & & & & & & & \\
\hline Startup had a board of directors & $\begin{array}{c}0.00169 * * \\
(2.10)\end{array}$ & $\begin{array}{l}0.00904 * * * \\
(3.49)\end{array}$ & $\begin{array}{c}0.00263^{* *} \\
(2.13)\end{array}$ & $\begin{array}{c}0.00344 * * \\
(2.15)\end{array}$ & $\begin{array}{c}0.00151 * * \\
(2.07)\end{array}$ & $\begin{array}{c}0.00427 * * \\
(2.20)\end{array}$ & $\begin{array}{c}0.00444 * * \\
(2.22)\end{array}$ & $\begin{array}{c}0.00448 * * \\
(2.31)\end{array}$ \\
\hline Number of outside board members & & & $\begin{array}{c}-0.00392^{*} \\
(-1.78)\end{array}$ & $\begin{array}{c}-0.00389 * \\
(-1.70)\end{array}$ & $\begin{array}{c}-0.00406^{*} \\
(-1.80)\end{array}$ & $\begin{array}{l}-0.00500^{* * *} \\
(-1.98)\end{array}$ & $\begin{array}{c}-0.00543^{*} \\
(-1.67)\end{array}$ & $\begin{array}{c}-0.00798 * \\
(-1.73)\end{array}$ \\
\hline Average board serving time & & & & & $\begin{array}{c}-0.000256 \\
(-0.44)\end{array}$ & & & \\
\hline Startup had Angel on board & $\begin{array}{l}0.0118 \\
(0.79)\end{array}$ & $\begin{array}{c}0.00867 \\
(0.58)\end{array}$ & $\begin{array}{c}0.00644 \\
(0.42)\end{array}$ & $\begin{array}{c}-0.00289 \\
(-0.17)\end{array}$ & $\begin{array}{c}0.00764 \\
(0.50)\end{array}$ & $\begin{array}{c}0.00869 \\
(0.57)\end{array}$ & $\begin{array}{l}0.000298 \\
(0.02)\end{array}$ & $\begin{array}{c}0.00614 \\
(0.40)\end{array}$ \\
\hline Startup had VC on board & $\begin{array}{c}0.0223^{*} \\
(1.73)\end{array}$ & $\begin{array}{l}0.0170^{*} \\
(1.94)\end{array}$ & $\begin{array}{c}0.0163^{*} \\
(1.89)\end{array}$ & $\begin{array}{c}0.0298^{*} \\
(1.90)\end{array}$ & $\begin{array}{c}0.0167 * \\
(1.91)\end{array}$ & $\begin{array}{l}0.00967 * * \\
\quad(2.45)\end{array}$ & $\begin{array}{c}0.0122^{*} \\
(1.66)\end{array}$ & $\begin{array}{l}0.0223^{* *} \\
(1.99)\end{array}$ \\
\hline Startup had inside chairman & & & $\begin{array}{c}-0.0196 \\
(-0.93)\end{array}$ & & & & & \\
\hline Startup had founder chairman & & & & $\begin{array}{r}-0.0101 \\
(-0.44)\end{array}$ & & & & \\
\hline Number of Financial Vehicle Corporations (FVC) on board & & & & & & & & $\begin{array}{l}-0.0178 \\
(-1.26)\end{array}$ \\
\hline Number of Corporate Venture Capital (CVC) on board & & & & & & & & $\begin{array}{l}-0.018 \\
(-0.33)\end{array}$ \\
\hline Financing Characteristics & & & & & & & & \\
\hline Total number of financing rounds & & & & & & & $\begin{array}{r}0.0101 \\
(1.48)\end{array}$ & \\
\hline Average growth rate of external financing amount & & & $\begin{array}{c}-0.000236 \\
(-0.52)\end{array}$ & $\begin{array}{c}-0.000204^{*} \\
(-1.86)\end{array}$ & $\begin{array}{c}-0.000241 \\
(-0.52)\end{array}$ & $\begin{array}{c}-0.000109 * * \\
(-2.23)\end{array}$ & $\begin{array}{c}-0.00028 \\
(-0.62)\end{array}$ & $\begin{array}{l}-0.000205 \\
(-0.45)\end{array}$ \\
\hline$\underline{\text { Market Conditions }}$ & & & & & & & & \\
\hline $\begin{array}{l}\text { Local MSCI Index Return on CEO Replacement Month } \\
\text { Interaction Variable }\end{array}$ & $\begin{array}{c}-0.0000227 \\
(-1.57)\end{array}$ & $\begin{array}{l}-0.0345 \\
(-1.59)\end{array}$ & $\begin{array}{c}-0.000773 * \\
(-1.68)\end{array}$ & $\begin{array}{c}-0.0306 * * \\
(-2.09)\end{array}$ & $\begin{array}{c}-0.0235^{* *} \\
(-2.36)\end{array}$ & $\begin{array}{l}-0.00732 * * \\
(-2.02)\end{array}$ & $\begin{array}{c}-0.0191 * * \\
(-2.35)\end{array}$ & $\begin{array}{c}-0.0196 * * \\
(-2.25)\end{array}$ \\
\hline Startup had VC on board * Startup had joined incubator & & & $\begin{array}{c}0.0239^{*} \\
(1.74)\end{array}$ & $\begin{array}{c}0.0241^{*} \\
(1.81)\end{array}$ & $\begin{array}{c}0.0239 * * \\
(2.19)\end{array}$ & $\begin{array}{c}0.0215 * * \\
(2.40)\end{array}$ & $\begin{array}{l}0.0263 * * \\
(2.49)\end{array}$ & $\begin{array}{l}0.0251^{* *} \\
(2.46)\end{array}$ \\
\hline CEO Replacement Year Fixed Effect & Yes & Yes & Yes & Yes & Yes & Yes & Yes & Yes \\
\hline Constant & $\begin{array}{c}0.183 * * * \\
(11.73)\end{array}$ & $\begin{array}{c}0.181 * * * \\
(11.46)\end{array}$ & $\begin{array}{c}0.181 * * * \\
(11.43)\end{array}$ & $\begin{array}{l}0.212 * * * \\
(11.49)\end{array}$ & $\begin{array}{l}0.194 * * * \\
(15.83)\end{array}$ & $\begin{array}{c}0.180 * * * \\
(11.31)\end{array}$ & $\begin{array}{c}0.172 * * * \\
(10.18)\end{array}$ & $\begin{array}{c}0.179 * * * \\
(11.28)\end{array}$ \\
\hline Observations & 251 & 251 & 251 & 251 & 251 & 251 & 251 & 251 \\
\hline R-squared & 0.013 & 0.033 & 0.04 & 0.018 & 0.037 & 0.042 & 0.045 & 0.043 \\
\hline $\mathrm{F}$ & $4.806^{* * *}$ & $6.344 * * *$ & $11.082 * * *$ & $7.336 * * *$ & $12.006 * * *$ & $16.023^{* * *}$ & $12.236^{* * *}$ & $9.046 * * *$ \\
\hline
\end{tabular}




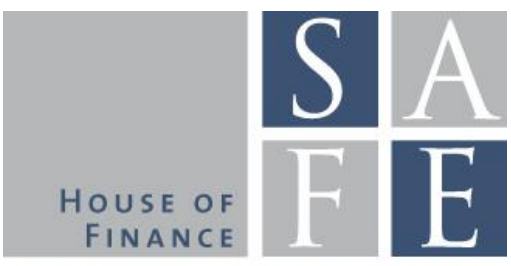

WORKING PAPER SERIES

\section{Recent Issues}

No.134 Markus Kröll, Devesh Rustagi

No. 133 Markus Behn, Rainer Haselmann, Thomas Kick, Vikrant Vig

No. 132 Rainer Haselmann, David Schoenherr, Vikrant Vig

No.131 Nicole Branger, Patrick Grüning, Christian Schlag

No.130 Giuliano Curatola

No. 129 Giuliano Curatola, Michael Donadelli, Patrick Grüning, Christoph Meinerding

No. 128 Giuliano Curatola

No. 127 Helmut Elsinger, Philipp SchmidtDengler, Christine Zulehner

No. 126 Carsten Bienz, Karin S. Thorburn, Uwe Walz

No. 125 Tobias H. Tröger, Uwe Walz

No. 124 Adrian Buss, Bernard Dumas, Raman Uppal, Grigory Vilkov

No. 123 Marie Lalanne, Paul Seabright
Got Milk? Motivation for Honesty and Cheating in Informal Markets: Evidence from India

The Political Economy of Bank Bailouts

Rent-Seeking in Elite Networks

Commodities, Financialization, and Heterogeneous Agents

Optimal Consumption and Portfolio Choice with Loss Aversion

Investment-Specific Shocks, Business Cycles, and Asset Prices

Preference Evolution and the Dynamics of Capital Markets

Competition in Treasury Auctions

Coinvestment and risk taking in private equity funds

Does Say on Pay Matter? Evidence from the German Natural Experiment

The Intended and Unintended Consequences of Financial-Market Regulations: A General Equilibrium Analysis

The Old Boy Network: The Impact of Professional Networks on Remuneration in Top Executive Jobs 